\title{
The Atmospheric Chemistry and Climate Model Intercomparison Project (ACCMIP): overview and description of models, simulations and climate diagnostics
}

J.-F. Lamarque ${ }^{1}$, D. T. Shindell ${ }^{2}$, B. Josse ${ }^{3}$, P. J. Young ${ }^{4,5,{ }^{*}}$, I. Cionni' ${ }^{6}$, V. Eyring ${ }^{7}$, D. Bergmann ${ }^{8}$, P. Cameron-Smith ${ }^{8}$, W. J. Collins ${ }^{9, * *}$, R. Doherty ${ }^{10}$, S. Dalsoren ${ }^{11}$, G. Faluvegi ${ }^{2}$, G. Folberth ${ }^{9}$, S. J. Ghan ${ }^{12}$, L. W. Horowitz ${ }^{13}$, Y. H. Lee ${ }^{2}$, I. A. MacKenzie ${ }^{10}$, T. Nagashima ${ }^{14}$, V. Naik ${ }^{15}$, D. Plummer ${ }^{16}$, M. Righi ${ }^{7}$, S. T. Rumbold ${ }^{9}$, M. Schulz ${ }^{17}$, R. B. Skeie ${ }^{11}$, D. S. Stevenson ${ }^{10}$, S. Strode ${ }^{18,19}$, K. Sudo ${ }^{14}$, S. Szopa ${ }^{20}$, A. Voulgarakis ${ }^{21}$, and G. Zeng ${ }^{22}$

${ }^{1}$ NCAR Earth System Laboratory, National Center for Atmospheric Research, Boulder, CO, USA

${ }^{2}$ NASA Goddard Institute for Space Studies and Columbia Earth Institute, New York, NY, USA

${ }^{3}$ GAME/CNRM, Météo-France, CNRS - Centre National de Recherches Météorologiques, Toulouse, France

${ }^{4}$ Cooperative Institute for Research in the Environmental Sciences, University of Colorado-Boulder, Boulder, CO, USA

${ }^{5}$ Chemical Sciences Division, NOAA Earth System Research Laboratory, Boulder, CO, USA

${ }^{6}$ Agenzia nazionale per le nuove tecnologie, l'energia e lo sviluppo economico sostenibile (ENEA), Bologna, Italy

${ }^{7}$ Deutsches Zentrum für Luft- und Raumfahrt (DLR), Institut für Physik der Atmosphäre, Oberpfaffenhofen, Germany

${ }^{8}$ Lawrence Livermore National Laboratory, Livermore, CA, USA

${ }^{9}$ Hadley Centre for Climate Prediction, Met Office, Exeter, UK

${ }^{10}$ School of Geosciences, University of Edinburgh, Edinburgh, UK

${ }^{11}$ Center for International Climate and Environmental Research-Oslo (CICERO), Oslo, Norway

${ }^{12}$ Pacific Northwest National Laboratory, Richland, WA, USA

${ }^{13}$ NOAA Geophysical Fluid Dynamics Laboratory, Princeton, NJ, USA

${ }^{14}$ Frontier Research Center for Global Change, Japan Marine Science and Technology Center, Yokohama, Japan

${ }^{15}$ UCAR/NOAA Geophysical Fluid Dynamics Laboratory, Princeton, NJ, USA

${ }^{16}$ Canadian Centre for Climate Modeling and Analysis, Environment Canada, Victoria, British Columbia, Canada

${ }^{17}$ Meteorologisk Institutt, Oslo, Norway

${ }^{18}$ NASA Goddard Space Flight Center, Greenbelt, MD, USA

${ }^{19}$ Universities Space Research Association, Columbia, MD, USA

${ }^{20}$ Laboratoire des Sciences du Climat et de l'Environnement, CEA/CNRS/UVSQ/IPSL, Gif-sur-Yvette, France

${ }^{21}$ Department of Physics, Imperial College, London, UK

${ }^{22}$ National Institute of Water and Atmospheric Research, Lauder, New Zealand

* now at: Lancaster Environment Centre, Lancaster University, Lancaster, UK

** now at: Department of Meteorology, University of Reading, UK

Correspondence to: J.-F. Lamarque (lamar@ucar.edu)

Received: 30 July 2012 - Published in Geosci. Model Dev. Discuss.: 28 August 2012

Revised: 21 December 2012 - Accepted: 7 January 2013 - Published: 7 February 2013

\begin{abstract}
The Atmospheric Chemistry and Climate Model Intercomparison Project (ACCMIP) consists of a series of time slice experiments targeting the long-term changes in atmospheric composition between 1850 and 2100, with the goal of documenting composition changes and the associated
\end{abstract}

radiative forcing. In this overview paper, we introduce the ACCMIP activity, the various simulations performed (with a requested set of 14) and the associated model output. The 16 ACCMIP models have a wide range of horizontal and vertical resolutions, vertical extent, chemistry schemes and 
Table 1. List and principal characteristics of ACCMIP simulations. Additional simulations (1890, 1910, 1950, 1970, and 1990) were proposed as Optional and are removed from this table for clarity. SSTs stands for sea surface temperatures and GHGs for greenhouse gases.

\begin{tabular}{|c|c|c|c|c|c|}
\hline \multicolumn{6}{|l|}{ Historical Simulations } \\
\hline Configuration & 1850 & 1930 & 1980 & 2000 & Name \\
\hline Emissions and SSTs/GHGs for given year & $\mathrm{P}$ & $\mathrm{P}$ & $\mathrm{P}$ & $\mathrm{P}$ & acchist \\
\hline Year 2000 emissions except 1850 SSTs and GHGs & $\mathrm{P}$ & & & & Em2000C11850 \\
\hline 2000 case except $1850 \mathrm{CH}_{4}$ concentration & & & & $\mathrm{O}$ & Em2000CH4185 \\
\hline 2000 case except $1850 \mathrm{NO}_{\mathrm{x}}$ emissions & & & & $\mathrm{O}$ & $\mathrm{Em} 2000 \mathrm{NO}_{\mathrm{X}} 185$ \\
\hline 2000 case except $1850 \mathrm{CO}$ emissions & & & & $\mathrm{O}$ & Em2000CO1850 \\
\hline 2000 case except 1850 NMHCs emissions & & & & $\mathrm{O}$ & Em2000NMVOC185 \\
\hline \multicolumn{6}{|l|}{ Future Simulations } \\
\hline Emissions/Configuration & 2010 & 2030 & 2050 & 2100 & Name \\
\hline RCP 2.6 (emissions, GHGs and SSTs) & & $\mathrm{P}$ & $\mathrm{O}$ & $P$ & accrcp26 \\
\hline RCP 4.5 (emissions, GHGs and SSTs) & $\mathrm{O}$ & $\mathrm{O}$ & $\mathrm{O}$ & $\mathrm{O}$ & accrcp 45 \\
\hline RCP 6.0 (emissions, GHGs and SSTs) & $\mathrm{P}$ & $\mathrm{P}$ & $\mathrm{O}$ & $\mathrm{P}$ & accrcp60 \\
\hline RCP 8.5 (emissions, GHGs and SSTs) & & $\mathrm{P}$ & $\mathrm{O}$ & $\mathrm{P}$ & accrcp85 \\
\hline Year 2000 emissions/RCP 8.5 SSTs and GHGs for 2030 & & $\mathrm{P}$ & & & Em2000Cl2030 \\
\hline Year 2000 emissions/RCP 8.5 SSTs and GHGs for 2100 & & & & $\mathrm{P}$ & Em2000C12100 \\
\hline
\end{tabular}

$\mathrm{P}=$ Primary, $\mathrm{O}=$ Optional, blank $=$ not requested

interaction with radiation and clouds. While anthropogenic and biomass burning emissions were specified for all time slices in the ACCMIP protocol, it is found that the natural emissions are responsible for a significant range across models, mostly in the case of ozone precursors. The analysis of selected present-day climate diagnostics (precipitation, temperature, specific humidity and zonal wind) reveals biases consistent with state-of-the-art climate models. The modelto-model comparison of changes in temperature, specific humidity and zonal wind between 1850 and 2000 and between 2000 and 2100 indicates mostly consistent results. However, models that are clear outliers are different enough from the other models to significantly affect their simulation of atmospheric chemistry.

\section{Introduction}

The Coupled Model Intercomparison Project (CMIP) is a protocol for (1) systematically defining model simulations to be performed with coupled atmosphere-ocean general circulation models (AOGCMs) and (2) studying the generated output. This framework provides the scientific community with the ability to more easily and meaningfully intercompare model results, a process which serves to facilitate model improvement. The simulations performed for the Climate Model Intercomparison Project phase 3 (CMIP3) in support of the Intergovernmental Panel on Climate Change (IPCC) Fourth Assessment Report (AR4) have provided a useful resource for exploring issues of climate sensitivity, historical climate and climate projections (e.g. Meehl et al., 2007 and references therein). However, the forcings imposed in simulations of the past or of the future varied from model to model due to varying assumptions about emissions (Shindell et al., 2008), differences in the representation of physical and biogeochemical processes affecting short-lived species that were included (such as aerosols and tropospheric ozone and its precursors), and differences in which processes and constituents were included at all (Pendergrass and Hartmann, 2012). For example, only 8 of 23 CMIP3 models included black carbon while fewer than half included future tropospheric ozone changes. Furthermore, the CMIP3 archive does not include diagnostics of spatially variable radiative forcing from aerosols, ozone, or greenhouse gases other than carbon dioxide. Hence it is not straightforward to understand how much of the variation between simulated climates results from internal climate sensitivity and inter-model differences or from differences in their forcings.

Similarly to CMIP3, there are gaps in the output from CMIP Phase 5 (CMIP5; note that the naming convention for CMIP was changed to align itself with the IPCC AR numbering, leading to the jump from CMIP3 to CMIP5) when it comes to atmospheric chemistry, with relatively little information on aerosols or greenhouse gases requested from models (Taylor et al., 2012). In particular, despite having relatively uniform anthropogenic emissions, natural emissions are likely highly diverse. Concentrations (forcings) will also differ between models due to different transformation/removal processes. This is especially the case as models progress towards a more Earth System approach and represent interactions with the biosphere (Arneth et al., 2010a), including climate-sensitive emissions of isoprene (Guenther et al., 2006; Arneth et al., 2010b), methane (O'Connor et al., 

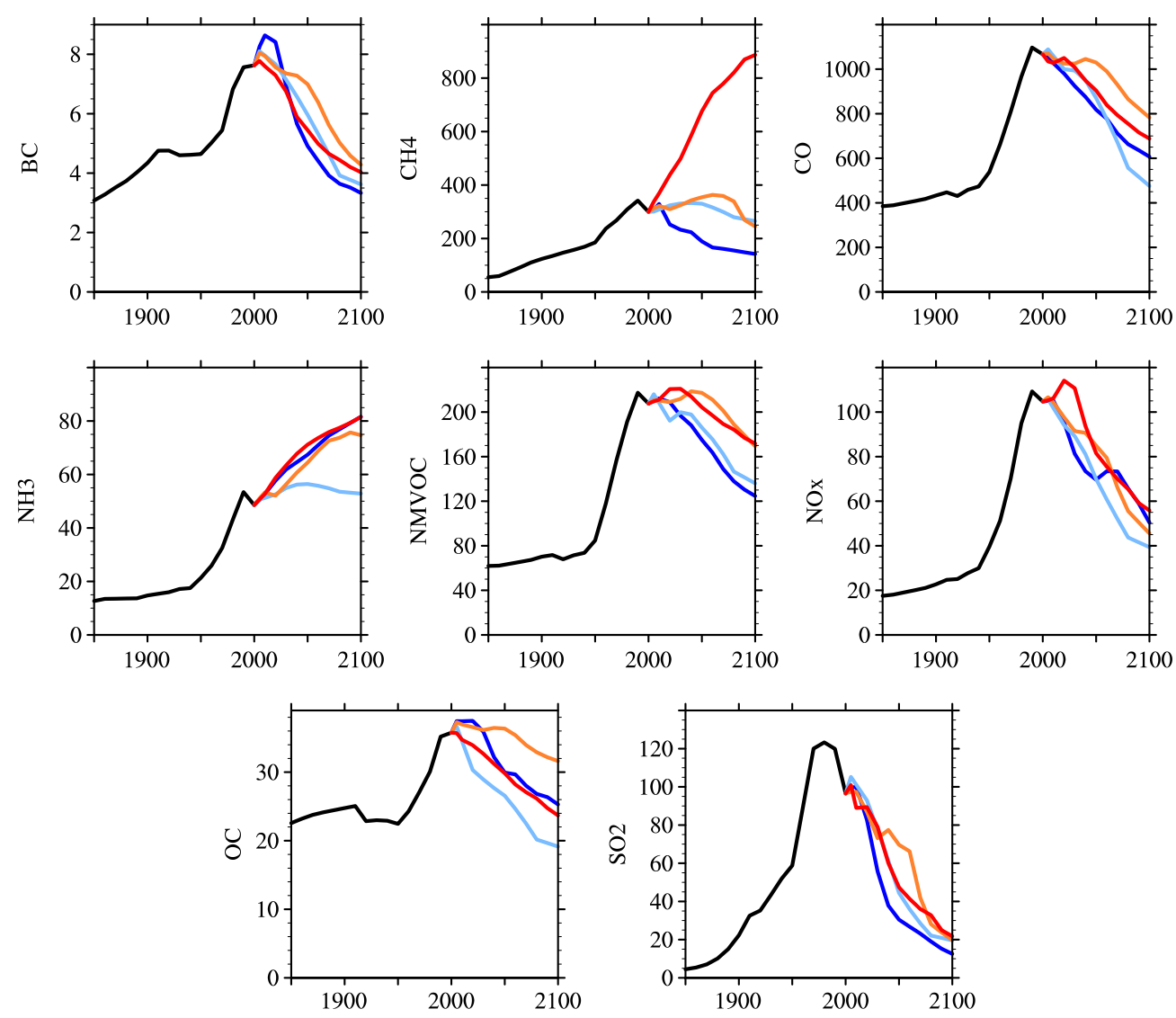

Fig. 1. Time evolution of global anthropogenic + biomass burning emissions 1850-2100 following each RCP; blue (RCP2.6), light blue (RCP4.5), orange (RCP6.0) and red (RCP8.5). BC represents black carbon (in $\mathrm{Tg}(\mathrm{C}) \mathrm{yr}^{-1}$ ), OC organic carbon (in $\mathrm{Tg}(\mathrm{C}) \mathrm{yr}^{-1}$ ), NMVOC non-methane volatile organic compounds (in $\left.\mathrm{Tg}(\mathrm{C}) \mathrm{yr}^{-1}\right)$ and $\mathrm{NO}_{\mathrm{x}}$ nitrogen oxides (in $\left.\mathrm{Tg}\left(\mathrm{NO}_{2}\right) \mathrm{yr}^{-1}\right)$. Other panels are in $\mathrm{Tg}(\mathrm{species}) \mathrm{yr} \mathrm{r}^{-1}$. Historical (1850-2000) values are from Lamarque et al. (2010). RCP values are from van Vuuren et al. (2011) and references therein.

2010) and soil nitrogen (Steinkamp and Lawrence, 2011), as well as the more standard climate-sensitive lightning emissions. Hence there is a need for characterization of the forcings imposed in the CMIP5 historical and future simulations, and for diagnostics to help understanding the causes of the differences in forcings from model to model.

The Atmospheric Chemistry and Climate Model Intercomparison Project (ACCMIP) aims to better evaluate the role of atmospheric chemistry in driving climate change, both gases and aerosols. Effectively, ACCMIP targets the analyses of the driving forces of climate change in the simulations being performed in CMIP5 (Taylor et al., 2012; note that in this document, ACCMIP is identified by the previous acronym, AC\&C\#4) in support of the upcoming IPCC Fifth Assessment Report (AR5). After an initial meeting in 2009, ACCMIP was organized at an April 2011 workshop where simulations, requested output and associated protocols and analysis teams were thoroughly defined. ACCMIP consists of a set of numerical experiments designed to provide insight into atmospheric chemistry driven changes in the
CMIP5 simulations of historical and future climate change, along with additional sensitivity simulations aiming to better understand the role of particular processes driving the non$\mathrm{CO}_{2}$ anthropogenic climate forcing (such as the aerosol indirect effects and the effects of specific precursors on tropospheric ozone). Finally, through its multi-model setup, ACCMIP provides a range in forcing estimates.

In addition, ACCMIP benefits from a wealth of new and updated observations related to atmospheric chemistry to evaluate and further our understanding of processes linking chemistry and climate. ACCMIP studies take advantage of these measurements by performing model evaluations, especially with respect to their simulations of tropospheric ozone and aerosols, both of which have substantial climate forcing that varies widely in space and time (Shindell et al., 2012). For this purpose, observations such as retrievals from the Tropospheric Emission Spectrometer (TES), the Ozone Monitoring Instrument (OMI), the Moderate Resolution Imaging Spectroradiometer (MODIS) on the Aura satellite, the Cloud-Aerosol Lidar and Infrared Pathfinder 
Table 2. List of participating models to and ACCMIP simulations performed. The number of years (valid for each experiment) is listed in the acchist 2000 column.

\begin{tabular}{|c|c|c|c|c|c|c|c|c|c|c|c|c|c|}
\hline \multirow[b]{2}{*}{ Model } & \multirow{2}{*}{$\begin{array}{c}\text { acchist } \\
1850\end{array}$} & \multirow[b]{2}{*}{1930} & \multirow[b]{2}{*}{1980} & \multicolumn{3}{|c|}{ accrep26 } & \multicolumn{2}{|l|}{ accrcp45 } & \multicolumn{2}{|c|}{ accrcp60 } & \multirow[b]{2}{*}{2100} & \multicolumn{2}{|c|}{ accrcp 85} \\
\hline & & & & 2000 & 2030 & 2100 & 2030 & 2100 & 2010 & 2030 & & 2030 & 2100 \\
\hline CESM-CAM-Superfast & $\mathrm{X}$ & $\mathrm{X}$ & $\mathrm{X}$ & 10 & $\mathrm{X}$ & $\mathrm{X}$ & & & $\mathrm{X}$ & $\mathrm{X}$ & $\mathrm{X}$ & $\mathrm{X}$ & $\mathrm{X}$ \\
\hline CICERO & $\mathrm{X}$ & $\mathrm{X}$ & $\mathrm{X}$ & 1 & $\mathrm{X}$ & $\mathrm{X}$ & $\mathrm{X}$ & $\mathrm{X}$ & & & & $\mathrm{X}$ & $\mathrm{X}$ \\
\hline CMAM & $\mathrm{X}$ & & $\mathrm{X}$ & 10 & & & $\mathrm{X}$ & $\mathrm{X}$ & & & & $\mathrm{X}$ & $\mathrm{X}$ \\
\hline EMAC-DLR & $\mathrm{X}$ & $\mathrm{X}$ & $\mathrm{X}$ & 10 & & & $\mathrm{X}$ & $\mathrm{X}$ & & & & $\mathrm{X}$ & $\mathrm{X}$ \\
\hline GEOSCCM & $\mathrm{X}$ & & $\mathrm{X}$ & 14 & & & & & & & $\mathrm{X}$ & & \\
\hline GFDL-AM3 & $\mathrm{X}$ & & $\mathrm{X}$ & 10 & $\mathrm{X}$ & $\mathrm{X}$ & $\mathrm{X}$ & $\mathrm{X}$ & & $\mathrm{X}$ & $\mathrm{X}$ & $\mathrm{X}$ & $\mathrm{X}$ \\
\hline GISS-E2-R & $\mathrm{X}$ & $\mathrm{X}$ & $\mathrm{X}$ & 11 & $\mathrm{X}$ & $\mathrm{X}$ & $\mathrm{X}$ & $\mathrm{X}$ & $\mathrm{X}$ & $\mathrm{X}$ & $\mathrm{X}$ & $\mathrm{X}$ & $\mathrm{X}$ \\
\hline GISS-E2-R-TOMAS & $\mathrm{X}$ & $\mathrm{X}$ & $\mathrm{X}$ & 10 & & & & & & & & & \\
\hline HADGEM2 & $\mathrm{X}$ & & $\mathrm{X}$ & 10 & & $\mathrm{X}$ & & $\mathrm{X}$ & & & & & $\mathrm{X}$ \\
\hline LMDZORINCA & $\mathrm{X}$ & $\mathrm{X}$ & $\mathrm{X}$ & 11 & $\mathrm{X}$ & $\mathrm{X}$ & $\mathrm{X}$ & $\mathrm{X}$ & $\mathrm{X}$ & $\mathrm{X}$ & $\mathrm{X}$ & $\mathrm{X}$ & $\mathrm{X}$ \\
\hline MIROC-CHEM & $\mathrm{X}$ & $\mathrm{X}$ & $\mathrm{X}$ & 10 & $\mathrm{X}$ & $\mathrm{X}$ & & & $\mathrm{X}$ & $\mathrm{X}$ & $\mathrm{X}$ & $\mathrm{X}$ & $\mathrm{X}$ \\
\hline MOCAGE & $\mathrm{X}$ & $\mathrm{X}$ & $\mathrm{X}$ & 4 & $\mathrm{X}$ & $\mathrm{X}$ & & & $\mathrm{X}$ & $\mathrm{X}$ & $\mathrm{X}$ & $\mathrm{X}$ & $\mathrm{X}$ \\
\hline NCAR-CAM3.5 & $\mathrm{X}$ & $\mathrm{X}$ & $\mathrm{X}$ & 8 & $\mathrm{X}$ & $\mathrm{X}$ & $\mathrm{X}$ & $\mathrm{X}$ & & $\mathrm{X}$ & $\mathrm{X}$ & $\mathrm{X}$ & $\mathrm{X}$ \\
\hline NCAR-CAM5.1 & $\mathrm{X}$ & $\mathrm{X}$ & $\mathrm{X}$ & 10 & & & & & & & & & \\
\hline STOC-HadAM3 & $\mathrm{X}$ & $\mathrm{X}$ & $\mathrm{X}$ & 10 & $\mathrm{X}$ & $\mathrm{X}$ & & & & & & $\mathrm{X}$ & $\mathrm{X}$ \\
\hline UM-CAM & $\mathrm{X}$ & $\mathrm{X}$ & $X$ & 10 & $\mathrm{X}$ & $\mathrm{X}$ & $\mathrm{X}$ & $\mathrm{X}$ & & & & $\mathrm{X}$ & $\mathrm{X}$ \\
\hline Model & $\begin{array}{c}\text { Em2000 } \\
\text { C11850 }\end{array}$ & $\begin{array}{c}\text { Em2000 } \\
\text { CH41850 }\end{array}$ & $\begin{array}{c}\text { Em2000 } \\
\text { NOx1850 }\end{array}$ & $\begin{array}{l}\text { Em2000 } \\
\text { CO1850 }\end{array}$ & $\begin{array}{c}\text { Em2000 } \\
\text { NMVOC1850 }\end{array}$ & $\begin{array}{c}\text { Em2000 } \\
\mathrm{Cl} 2030\end{array}$ & $\begin{array}{c}\text { Em2000 } \\
\text { Cl2100 }\end{array}$ & & & & & & \\
\hline $\begin{array}{l}\text { CESM-CAM-Superfast } \\
\text { CICERO } \\
\text { CMAM }\end{array}$ & $\mathrm{X}$ & $\mathrm{X}$ & $\mathrm{X}$ & $\mathrm{X}$ & $\mathrm{X}$ & $\mathrm{X}$ & $\mathrm{X}$ & & & & & & \\
\hline $\begin{array}{l}\text { EMAC-DLR } \\
\text { GEOSCCM }\end{array}$ & $\mathrm{X}$ & & & & & $\mathrm{X}$ & $\mathrm{X}$ & & & & & & \\
\hline $\begin{array}{l}\text { GFDL-AM3 } \\
\text { GISS-E2-R } \\
\text { GISS-E2-R-TOMAS } \\
\text { HADGEM2 } \\
\text { LMDZORINCA } \\
\text { MIROC-CHEM }\end{array}$ & $\mathrm{X}$ & $\mathrm{X}$ & & & & $\mathrm{X}$ & $\mathrm{X}$ & & & & & & \\
\hline MOCAGE & $\mathrm{X}$ & & & & & $\mathrm{X}$ & $\mathrm{X}$ & & & & & & \\
\hline NCAR-CAM3.5 & $\mathrm{X}$ & $\mathrm{X}$ & $\mathrm{X}$ & $\mathrm{X}$ & $\mathrm{X}$ & $\mathrm{X}$ & $\mathrm{X}$ & & & & & & \\
\hline $\begin{array}{l}\text { NCAR-CAM5.1 } \\
\text { STOC-HadAM3 }\end{array}$ & $\mathrm{X}$ & & & & & & & & & & & & \\
\hline UM-CAM & $\mathrm{X}$ & $\mathrm{X}$ & $\mathrm{X}$ & $\mathrm{X}$ & $\mathrm{X}$ & $\mathrm{X}$ & $\mathrm{X}$ & & & & & & \\
\hline
\end{tabular}

Satellite Observations (CALIPSO), and the ground-based Aerosol Robotic Network (Aeronet) will be used.

This paper is the ACCMIP overview paper and as such serves as a central repository of information relevant to the ACCMIP simulations (of which 14 were requested), the 16 models performing them and the various ACCMIP papers presently submitted to the Atmospheric Chemistry and Physics ACCMIP Special Issue, discussing (1) aerosols and total radiative forcing (Shindell et al., 2012a), (2) historical and future changes in tropospheric ozone (Young et al., 2012), (3) tropospheric ozone radiative forcing and attribution (Stevenson et al., 2012), (4) ozone comparison with TES (Bowman et al., 2012), (5) black carbon deposition (Lee et al., 2012) and (6) OH (hydroxyl radical) and methane lifetime in the historical (Naik et al., 2012a) and future (Voulgarakis et al., 2012) simulations. As such, we present here only the overall suite of model characteristics, simulations performed and evaluation of selected climate variables, since the evaluation and analysis of chemical composition and indepth model descriptions will be addressed as needed in each paper.
The paper is organized as follows: in Sect. 2, we provide an overview of the ACCMIP simulations. Section 3 describes the main characteristics of the participating models. Section 4 focuses on the evaluation of the present-day simulations against observations, with a particular focus on selected physical climate variables (precipitation, specific humidity, temperature and zonal wind). Section 5 provides a description of the climate response to simulated historical and projected changes in the same physical climate variables. Section 6 presents a brief discussion and overall conclusions.

\section{Description of simulations, output protocol and data access}

The ACCMIP simulations (Table 1) consist of time slice experiments (for specific periods spanning 1850 to 2100 with a minimum increment of $10 \mathrm{yr}$ ) with chemistry diagnostics, providing information on the anthropogenic forcing of historical and future climate change in the CMIP5 simulations, including the chemical composition changes associated with this forcing. Each requested simulation is labeled as Primary 

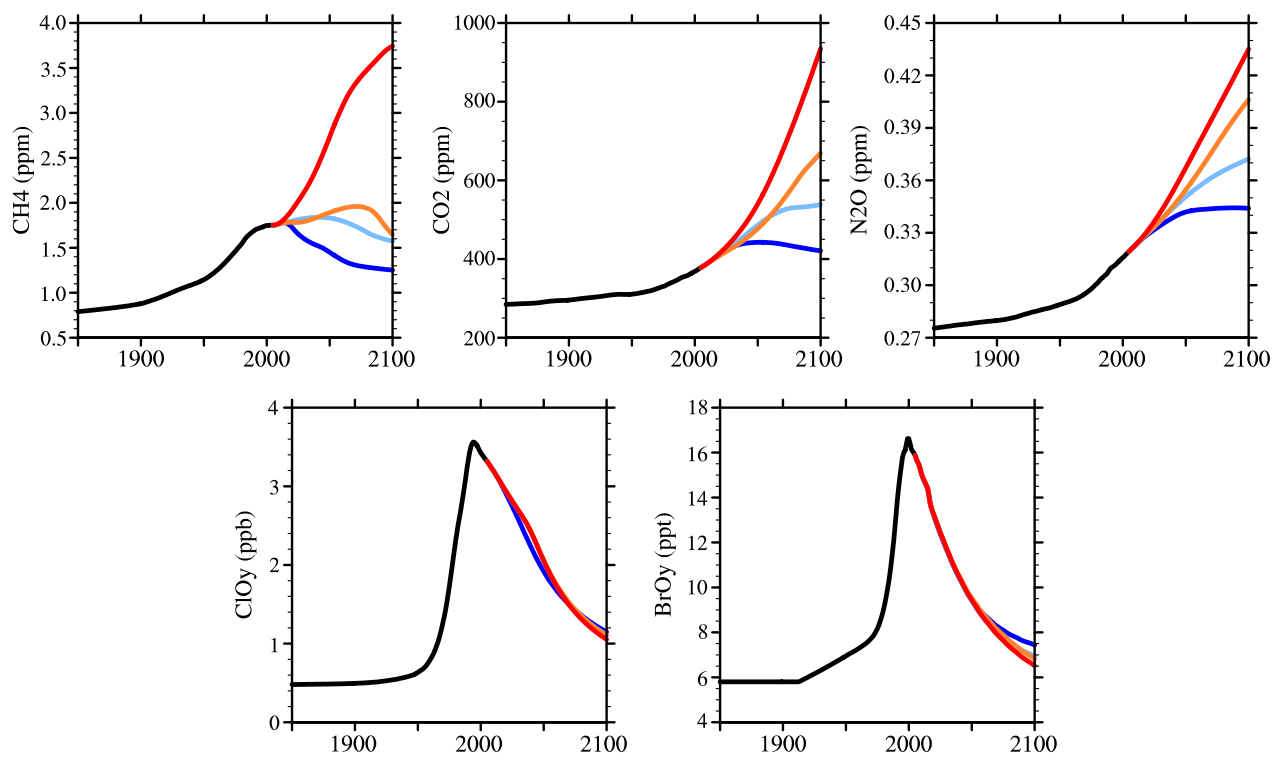

Fig. 2. Time evolution of global-averaged mixing ratio of long-lived species 1850-2100 following each RCP; blue (RCP2.6), light blue (RCP4.5), orange (RCP6.0) and red (RCP8.5). ClOy and BrOy are the total organic chlorine and bromine compounds, respectively, summarizing the evolution of ozone-depleting substances. All values from Meinshausen et al. (2011).

("P") or Optional ("O"). Note that additional simulations (additional time slices or sensitivity tests) were performed by only a limited number of modeling groups. For clarity, they are not listed in Table 1 but will be referred to in some of the ACCMIP papers.

Figures 1 and 2 show the prescribed evolution of shortlived precursor emissions and long-lived specie concentrations for the different periods and scenarios in the study. For the historical period, beyond the "pre-industrial" (representative of year 1850 emissions) and "present-day" (representative of year 2000 emissions) time slices, we have included 1930 (beginning of the large increase in global anthropogenic emissions) and 1980 (peak in anthropogenic emissions over Europe and North America).

Projection simulations follow the Representative Concentration Pathways (RCPs; van Vuuren et al., 2011 and references therein) for both short-lived precursor emissions (Fig. 1) and long-lived specie concentrations (Fig. 2; Meinshausen et al., 2011). Amongst the 4 available RCPs, a higher simulation priority was given to RCP6.0 since it has shortlived precursor emissions significantly different from the other RCPs, especially in the first half of the 21st century (Fig. 1); however, RCP2.6 and RCP8.5 are still scientifically important since they provide the extremes in terms of 2100 climate change and methane levels. In addition to the primary simulations at 2030 and 2100, an optional time slice at 2050 is included as this time horizon is of interest to policy makers.

Additional simulations were completed, using 2000 emissions but with an 1850, 2030 and 2100 (both with RCP8.5) climate, to separate the effects of climate change and
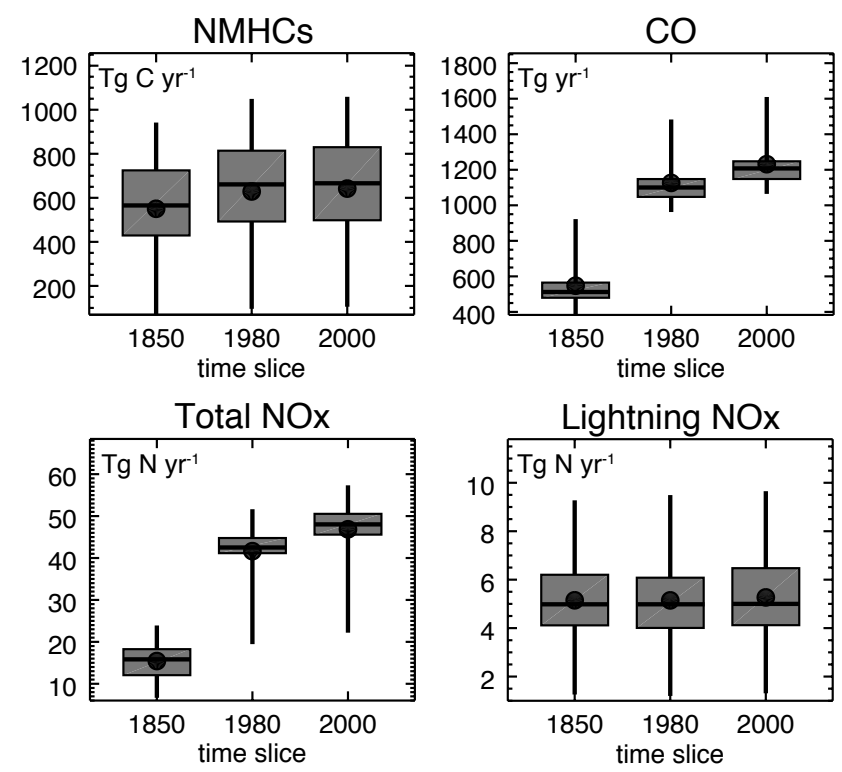

Fig. 3. Time evolution of historical total (anthropogenic + biomass burning + natural) emissions of $\mathrm{NO}_{\mathrm{x}}, \mathrm{CO}$ and NMHCs. In addition, lightning emissions are shown. For each time slice, the filled circle indicates the mean, the solid line the median, the extent of the box is $25-75 \%$ and minimum and maximum are shown (adapted from Young et al., 2012).

emissions on constituents and for isolating aerosol indirect effects. In these, the sea surface temperatures and long-lived specie concentrations were specified following their values in the target climate. 
Table 3. Model description summary.

\begin{tabular}{|c|c|c|c|c|}
\hline & Model & Modelling Center & Model Contact & Reference \\
\hline 1 & CESM-CAM-Superfast & LLNL, USA & $\begin{array}{c}\text { Dan Bergmann } \\
\text { Philip Cameron-Smith }\end{array}$ & Lamarque et al. (2012) \\
\hline 2 & CICERO-OsloCTM2 & CICERO, Norway & $\begin{array}{c}\text { Stig Dalsoren } \\
\text { Ragnhild Skeie }\end{array}$ & Skeie et al. $(2011 \mathrm{a}, \mathrm{b})$ \\
\hline 3 & CMAM & $\begin{array}{l}\text { CCCMA, Environment } \\
\text { Canada, Canada }\end{array}$ & David Plummer & Scinocca et al. (2008) \\
\hline 4 & EMAC & DLR, Germany & $\begin{array}{l}\text { Patrick Jöckel, } \\
\text { Veronika Eyring } \\
\text { Mattia Righi } \\
\text { Irene Cionni }\end{array}$ & Jöckel et al. (2006) \\
\hline 5 & GEOSCCM & NASA GSFC, USA & Sarah Strode & Oman et al. (2011) \\
\hline 6 & GFDL-AM3 & $\begin{array}{c}\text { UCAR/NOAA, } \\
\text { GFDL, USA }\end{array}$ & $\begin{array}{l}\text { Larry Horowitz, } \\
\text { Vaishali Naik }\end{array}$ & $\begin{array}{l}\text { Donner et al. (2011) } \\
\text { Naik et al. (2012b) }\end{array}$ \\
\hline 7 & GISS-E2-R(-TOMAS) & NASA-GISS,USA & $\begin{array}{l}\text { Drew Shindell } \\
\text { Greg Faluvegi }\end{array}$ & $\begin{array}{l}\text { Koch et al. (2006) } \\
\text { Shindell et al. (2012b) }\end{array}$ \\
\hline 8 & GISS-E2-R-TOMAS & NASA-GISS,USA & $\begin{array}{l}\text { Drew Shindell } \\
\text { Greg Faluvegi } \\
\text { Yunha Lee }\end{array}$ & $\begin{array}{l}\text { Lee and Adams (2011) } \\
\text { Shindell et al. (2012b) }\end{array}$ \\
\hline 9 & HadGEM2 & $\begin{array}{l}\text { Hadley Center, } \\
\text { Met.Office, UK }\end{array}$ & $\begin{array}{l}\text { William Collins } \\
\text { Gerd Folbert } \\
\text { Steve Rumbold }\end{array}$ & Collins et al. (2011) \\
\hline 10 & LMDzORINCA & $\begin{array}{l}\text { LSCE, CEA/CNRS } \\
\text { /UVSQ/IPSL, France }\end{array}$ & Sophie Szopa & Szopa et al. (2012) \\
\hline 11 & MIROC-CHEM & $\begin{array}{c}\text { FRCGC, JMSTC } \\
\text { Japan }\end{array}$ & $\begin{array}{l}\text { Tatsuya Nagashima } \\
\text { Kengo Sudo }\end{array}$ & Watanabe et al. (2011) \\
\hline 12 & MOCAGE & $\begin{array}{c}\text { GAME/CNRM } \\
\text { MétéoFrance, France }\end{array}$ & Béatrice Josse & $\begin{array}{c}\text { Josse et al. (2004) } \\
\text { Teyssèdre et al. (2007) }\end{array}$ \\
\hline 13 & NCAR-CAM3.5 & NCAR,USA & Jean-François Lamarque & Lamarque et al. $(2011,2012)$ \\
\hline 14 & NCAR-CAM5.1 & PNNL, USA & Steve Ghan & X. Liu et al. (2012) \\
\hline 15 & STOC-HadAM3 & $\begin{array}{l}\text { University of } \\
\text { Edinburgh,UK }\end{array}$ & $\begin{array}{l}\text { Ian McKenzie } \\
\text { David Stevenson } \\
\text { Ruth Doherty }\end{array}$ & Stevenson et al. (2004) \\
\hline 16 & UM-CAM & NIWA, New Zealand & Guang Zeng & Zeng et al. $(2008,2010)$ \\
\hline
\end{tabular}

As variations in the solar activity since 1850 is of limited importance for tropospheric chemistry, no specification was made in the ACCMIP protocol. Suggested volcanoes and associated stratospheric surface area density follow CCMVal (http://www.pa.op.dlr.de/CCMVal/Forcings/ CCMVal_Forcings_WMO2010.html), with no volcanic eruptions in the future.

The proposed simulation length was $4-10 \mathrm{yr}$ (excluding spinup, see Table 2) using prescribed monthly sea surface temperature (SST) and sea ice concentration (SIC) distributions, valid for each time slice and averaged over $10 \mathrm{yr}$. This averaging was designed to reduce the effect of interannual variability and therefore provide optimal conditions from which average composition changes and associated forcings can be more readily computed. Output from transient simulations performed with two coupled chemistryclimate-ocean models (i.e. CMIP5 runs, performed by GISSE2-R and LMDzORINCA) is also part of the ACCMIP data collection. For the analysis of these models, output fields were averaged over an 11-yr window centered on the target time-slice year (e.g. 2025-2035 for the 2030 time slice).

\subsection{Emissions and concentration boundary conditions}

Consistent gridded emissions data from 1850 to 2100 were created in support of CMIP5 and of this activity; the historical (1850-2000) portion of this dataset is discussed in Lamarque et al. (2010). The year 2000 dataset was used for harmonization with the future emissions determined by Integrated Assessment Models (IAMs) for the four RCPs described in van Vuuren et al. (2011) and references therein. As shown in Fig. 1, all emissions necessary for the simulation of tropospheric ozone and aerosols between 1850 and 2100 are available for both anthropogenic activities (including biofuel, shipping and aircraft) and biomass burning. 
Table 3. Continued.

\begin{tabular}{|c|c|c|c|}
\hline Model & Type & $\begin{array}{l}\text { Resolution (lat/lon/\# levels), } \\
\text { Top level }\end{array}$ & Methane \\
\hline CESM-CAM-Superfast & $\mathrm{CCM}$ & $1.875 / 2.5 / \mathrm{L} 26,3.5 \mathrm{hPa}$ & $\begin{array}{l}\text { Prescribed atmospheric concentrations with spatial } \\
\text { variation, different for each time slice }\end{array}$ \\
\hline CICERO-OsloCTM2 & CTM & 2.8/2.8/L60, $0.11 \mathrm{hPa}$ & $\begin{array}{l}\text { Prescribed surface concentrations - zonal averages from } \\
\text { IPCC TAR for historical; CMIP5 surface concentrations } \\
\text { scaled to be consistent with present-day levels in the } \\
\text { historical simulations for RCP simulations }\end{array}$ \\
\hline CMAM & $\mathrm{CCM}$ & $3.75 / 3.75 / \mathrm{L} 71,0.00081 \mathrm{hPa}$ & $\begin{array}{l}\text { Prescribed year-specific surface concentrations follow- } \\
\text { ing CMIP5. Different in each time slice }\end{array}$ \\
\hline EMAC & $\mathrm{CCM}$ & $\mathrm{T} 42 / \mathrm{L} 90,0.01 \mathrm{hPa}$ & $\begin{array}{l}\text { Prescribed surface concentrations (following CMIP5), } \\
\text { different in each time slice }\end{array}$ \\
\hline GEOSCCM & $\mathrm{CCM}$ & $2 / 2.5 / \mathrm{L} 72,0.01 \mathrm{hPa}$ & $\begin{array}{l}\text { Prescribed surface (two bottom levels) concentrations. } \\
\text { Surface methane has a prescribed latitudinal gradient, } \\
\text { normalized to match the CMIP5 value at the time slice } \\
\text { period }\end{array}$ \\
\hline GFDL-AM3 & $\mathrm{CCM}$ & 2/2.5/L48, $0.017 \mathrm{hPa}$ & $\begin{array}{l}\text { Prescribed surface concentrations (following CMIP5), } \\
\text { different in each time slice }\end{array}$ \\
\hline GISS-E2-R(-TOMAS) & $\mathrm{CCM}$ & $2 / 2.5 / \mathrm{L} 40,0.14 \mathrm{hPa}$ & $\begin{array}{l}\text { Prescribed surface concentrations for historical (follow- } \\
\text { ing CMIP5), emissions for future }\end{array}$ \\
\hline HadGEM2 & $\mathrm{CCM}$ & 1.24/1.87/L38, hPa & Prescribed surface concentrations \\
\hline LMDzORINCA & $\mathrm{CCM}$ & 1.9/3.75/L19, hPa & Emissions for historical and future \\
\hline MIROC-CHEM & $\mathrm{CCM}$ & $2.8 / 2.8 / \mathrm{L} 80,0.003 \mathrm{hPa}$ & $\begin{array}{l}\text { Prescribed surface concentrations (following CMIP5), } \\
\text { different in each time slice }\end{array}$ \\
\hline MOCAGE & CTM & 2.0/2.0/L47, $6.9 \mathrm{hPa}$ & $\begin{array}{l}\text { Prescribed surface concentrations (following CMIP5), } \\
\text { different in each time slice }\end{array}$ \\
\hline NCAR-CAM3.5 & $\mathrm{CCM}$ & $1.875 / 2.5 / \mathrm{L} 26,3.5 \mathrm{hPa}$ & $\begin{array}{l}\text { Prescribed surface concentrations (following CMIP5), } \\
\text { different in each time slice }\end{array}$ \\
\hline NCAR-CAM5.1 & $\mathrm{CCM}$ & $1.875 / 2.5 / \mathrm{L} 30,3.5 \mathrm{hPa}$ & Prescribed distributions from NCAR-CAM3.5 \\
\hline STOC-HadAM3 & CGCM & $5.0 / 5.0 / \mathrm{L} 19,50 \mathrm{hPa}$ & $\begin{array}{l}\text { Prescribed globally uniform } \mathrm{CH}_{4} \text { concentrations. } \\
\text { Different for each time slice following CMIP5 dataset }\end{array}$ \\
\hline UM-CAM & CGCM & $2.5 / 3.75 / \mathrm{L} 19,4.6 \mathrm{hPa}$ & $\begin{array}{l}\text { Prescribed atmospheric concentration with no spatial } \\
\text { variation; different for each time slice }\end{array}$ \\
\hline
\end{tabular}

Concentrations of long-lived chemical species and greenhouse gases were based on the observed historical record (1850-2005) and on the RCP emissions, converted to concentrations by Meinshausen et al. (2011) and shown in Fig. 2.

Unlike anthropogenic and biomass burning emissions, natural emissions (mostly isoprene, lightning and soil $\mathrm{NO}_{\mathrm{x}}$, oceanic emissions of $\mathrm{CO}$, dimethylsulfide, $\mathrm{NH}_{3}$, and emissions of non-erupting volcanoes) were not specified. No attempts were made at harmonizing natural emissions between modeling groups, leading to a range in emissions (Fig. 3). A summary of the emissions as implemented in each model is listed in Table 3 and further discussion on variations between model natural emissions is provided in Sect. 3 .

\subsection{Simulation output}

The ACCMIP simulations provide as output the concentration or mass of radiatively active species, aerosol optical properties, and radiative forcings (clear and all sky).
Furthermore, the output also includes important diagnostics to document these, such as the hydroxyl radical concentration, photolysis rates, various ozone budget terms (e.g. production and loss rates and dry deposition flux), specific chemical reaction rates, nitrogen and sulfate deposition rates, emission rates, high-frequency (hourly) surface pollutant concentrations $\left(\mathrm{O}_{3}, \mathrm{NO}_{2}\right.$ and $\left.\mathrm{PM}_{2.5}\right)$ and diagnostics of tracer transport. A complete list of the monthly output is provided as Table S1. For all variables, Climate Model Output Rewriter (CMOR, see http://www2-pcmdi.llnl.gov/cmor) tables have been created, based in part on protocols defined for previous model intercomparisons, such as Hemispheric Transport of Air Pollutants (HTAP, see http://www.htap. org), Aerosol Comparisons between Observations and Models (AeroCOM, see http://aerocom.met.no/), and ChemistryClimate Model Validation (CCMVal, see http://www.pa.op. dlr.de/CCMVal). All ACCMIP-generated data follow standardized netCDF formats and use Climate and Forecast (CF; 
Table 3. Continued.

\begin{tabular}{|c|c|c|}
\hline Model & Lightning $\mathrm{NO}_{\mathrm{x}}$ & Other Natural emissions \\
\hline CESM-CAM-Superfast & $\begin{array}{l}\text { Interactive, based on model's convection (Price } \\
\text { et al., 1997) }\end{array}$ & $\begin{array}{l}\text { Constant present-day isoprene, } \mathrm{CH}_{2} \mathrm{O} \text {, soil } \\
\mathrm{NO}_{\mathrm{x}}, \mathrm{DMS} \text { and volcanic sulfur, oceanic } \mathrm{CO}\end{array}$ \\
\hline CICERO-OsloCTM2 & $\begin{array}{l}\text { Interactive, based on model's convection (Price } \\
\text { et al., 1997) and scaled to } 5 \mathrm{Tg} \mathrm{N} \mathrm{yr}^{-1}\end{array}$ & $\begin{array}{l}\text { Constant present-day (year 2000). From the } \\
\text { RETRO dataset: CO, } \mathrm{NO}_{\mathrm{x}}, \mathrm{C}_{2} \mathrm{H}_{4}, \mathrm{C}_{2} \mathrm{H}_{6} \text {, } \\
\mathrm{C}_{3} \mathrm{H}_{6}, \mathrm{C}_{3} \mathrm{H}_{8}, \text { ISOPRENE, ACETONE. Vari- } \\
\text { ous datasets: } \mathrm{SO}_{2}, \mathrm{H}_{2} \mathrm{~S} \text {, DMS,TERPENES, sea } \\
\text { salt, } \mathrm{NH}_{3}\end{array}$ \\
\hline СMAM & $\begin{array}{l}\text { Interactive, based on convective updraft mass } \\
\text { flux (modified version of Allen and Pickering, } \\
\text { 2002) }\end{array}$ & $\begin{array}{l}\text { Constant; pre-industrial soil } \mathrm{NO}_{\mathrm{x}} \text { emission of } \\
8.7 \mathrm{Tg} \mathrm{N} \mathrm{yr}^{-1} \text { plus CMIP5 Agriculture (soil) } \\
\text { anthropogenic enhancement; CO emissions of } \\
250 \mathrm{TgCO}^{-1} \text { as proxy for isoprene oxidation } \\
\text { distributed as Guenther et al. (1995) }\end{array}$ \\
\hline EMAC & $\begin{array}{l}\text { Interactive, updraft velocity as a measure of } \\
\text { convective strength and associated cloud elec- } \\
\text { trification with the flash frequency (Grewe } \\
\text { et al., 2001) }\end{array}$ & $\begin{array}{l}\text { Climate sensitive soil } \mathrm{NO}_{\mathrm{x}} \text {, isoprene and light- } \\
\text { ning } \mathrm{NO}_{\mathrm{x}} \text { and soil NO. Constant present-day } \\
\text { (year 2000) } \mathrm{SO}_{2} \text { emissions from volcanoes } \\
\text { (Dentener et al., 2006), biogenic emissions of } \\
\mathrm{CO} \text { and VOC (Ganzeveld et al., 2006), terres- } \\
\text { trial DMS (Spiro et al., 1992) }\end{array}$ \\
\hline GEOSCCM & $\begin{array}{l}\text { Fixed emissions with a monthly climatology } \\
\text { based on Price et al., scaled to } 5 \mathrm{Tg} \mathrm{N} \mathrm{yr}^{-1}\end{array}$ & $\begin{array}{l}\text { Climate-sensitive soil } \mathrm{NO}_{\mathrm{x}} \text { and biogenic VOC } \\
\text { emissions of isoprene and } \mathrm{CO} \text { from monoter- } \\
\text { pene. Biogenic propene and } \mathrm{CO} \text { from methanol } \\
\text { is scaled from isoprene. No oceanic } \mathrm{CO}\end{array}$ \\
\hline GFDL-AM3 & $\begin{array}{l}\text { Interactive, based on model's convection (Price } \\
\text { et al., 1997), scaled to produce } \sim 3-5 \mathrm{TgN} \text {. }\end{array}$ & $\begin{array}{l}\text { constant pre-industrial soil } \mathrm{NO}_{\mathrm{x}} \text {; constant } \\
\text { present-day soil and oceanic } \mathrm{CO} \text {, and biogenic } \\
\text { VOC; climate-sensitive dust, sea salt, and DMS }\end{array}$ \\
\hline $\begin{array}{l}\text { GISS-E2-R } \\
\text { (-TOMAS) }\end{array}$ & $\begin{array}{l}\text { Interactive, based on model's convection (mod- } \\
\text { ified from Price et al., 1997) }\end{array}$ & $\begin{array}{l}\text { Climate-sensitive isoprene based on present- } \\
\text { day vegetation, climate sensitive dust, sea salt, } \\
\text { DMS; constant present-day soil } \mathrm{NO}_{\mathrm{x}} \text {, alkenes, } \\
\text { paraffin }\end{array}$ \\
\hline HadGEM2 & $\begin{array}{l}\text { Interactive, based on model's convection (Price } \\
\text { and Rind, 1992) }\end{array}$ & $\begin{array}{l}\text { Prescribed: soil } \mathrm{NO}_{\mathrm{x}}, \mathrm{BVOC} \text { (as } \mathrm{CO} \text { ), DMS } \\
\text { Climate sensitive: sea salt, dust }\end{array}$ \\
\hline LMDzORINCA & $\begin{array}{l}\text { Interactive, based on model's convection (Price } \\
\text { et al., 1997) }\end{array}$ & $\begin{array}{l}\text { Constant soil } \mathrm{NO}_{\mathrm{x}} \text {, oceanic } \mathrm{CO} \text { (no soil } \\
\mathrm{CO} \text { ) and oxygenated biogenic compounds for } \\
\text { present-day }\end{array}$ \\
\hline MIROC-CHEM & $\begin{array}{l}\text { Interactive, based on model's convection based } \\
\text { on Price and Rind (1992) }\end{array}$ & $\begin{array}{l}\text { Constant present-day VOCs, soil-Nox, oceanic- } \\
\text { CO (no soil CO); climate-sensitive dust, sea } \\
\text { salt, DMS }\end{array}$ \\
\hline MOCAGE & $\begin{array}{l}\text { Climate sensitive (based on Price and Rind, } \\
1992 \text { and Ridley et al., 2005) }\end{array}$ & $\begin{array}{l}\text { Constant present-day isoprene, Other VOCs, } \\
\text { Oceanic CO, Soil NOx }\end{array}$ \\
\hline NCAR-CAM3.5 & $\begin{array}{l}\text { Interactive, based on model's convection (Price } \\
\text { et al., 1997; Ridley et al., 2005), scaled to pro- } \\
\text { duce } \sim 3-5 \text { Tg N. }\end{array}$ & $\begin{array}{l}\text { Constant pre-industrial soil } \mathrm{NO}_{\mathrm{x}} \text { emissions, } \\
\text { constant present-day biogenic isoprene, bio- } \\
\text { genic and oceanic } \mathrm{CO} \text {, other VOCs and DMS; } \\
\text { climate-sensitive dust, sea salt }\end{array}$ \\
\hline NCAR-CAM5.1 & NA & $\begin{array}{l}\text { Sea salt, DMS, mineral dust, wildfire } \\
\text { BC\&POA, smoldering volcanic } \mathrm{SO}_{2}\end{array}$ \\
\hline STOC-HadAM3 & $\begin{array}{l}\text { Interactive, based on model's convection (Price } \\
\text { and Rind, 1992; Price et al., 1997) }\end{array}$ & $\begin{array}{l}\text { Constant, present-day emissions of } \mathrm{NO}, \mathrm{CO} \text {, } \\
\mathrm{NH}_{3} \text {, VOC, DMS and } \mathrm{H}_{2} \text { from veg, soil } \\
\text { and ocean. Present-day volcanic } \mathrm{SO}_{2} \text {. Climate- } \\
\text { sensitive isoprene }\end{array}$ \\
\hline UM-CAM & $\begin{array}{l}\text { Climate sensitive; based on parameterization } \\
\text { from Price and Rind (1997) }\end{array}$ & $\begin{array}{l}\text { Constant present-day biogenic isoprene, soil } \\
\mathrm{NO}_{\mathrm{x}} \text {, biogenic and oceanic } \mathrm{CO}\end{array}$ \\
\hline
\end{tabular}


Table 3. Continued.

\begin{tabular}{ll}
\hline Model & SSTs/SICE \\
\hline CESM-CAM-Superfast & Decadal means from fully coupled CESM-CAM model simulation for CMIP5, except for the \\
& RCP2.6 and RCP6.0 simulations which used SSTs from an earlier version (CCSM3) \\
CICERO-OsloCTM2 & CTM. Met fields: Forecast data for year 2006 from ECMWF IFS model \\
CMAM & Decadal means from two members of CCCma CanESM2 CMIP5 simulations \\
EMAC & Decadal means from the CMIP5 run carried out with the CMCC Climate Model \\
GEOSCCM & 1870s AMIP SSTs for the 1850 time slice, http://www-pcmdi.llnl.gov/projects/amip/ \\
& AMIP2EXPDSN/BCS/bcsintro.php, based on HadISST v1 and NOAA OI SST v2 (Hurrell \\
& et al., 2008). SSTs from the CCSM4 for 2100 RCP60 time slice (Meehl et al., 2012) \\
GFDL-AM3 & Decadal mean SSTs/SICE from one member of GFDL-CM3 CMIP5 simulations \\
GISS-E2-R(-TOMAS) & Transient, with simulated SSTs/SICE (CMIP5/ACCMIP runs) \\
HadGEM2 & HadGEM2 CMIP5 transient run for the appropriate time period (Jones et al., 2011). \\
LMDzORINCA & SSTs/SICE from HadiSST for historical and from AR4 simulations of IPSL-CM4 ESM (B1, \\
& A1B, and A2 for 4.5, 6.0, and 8.5, respectively, and scenario E1 (van Vuuren et al., 2007) for \\
RCP2.6) & monthly mean SSTs/SICE from MIROC-ESM CMIP5 simulations; data for the corresponding \\
MIROC-CHEM & ACCMIP time slice year is used and repeated over the years of model integration \\
MOCAGE & No SSTs/SICE (CTM); met. fields taken from atmosphere-only ARPEGE-Climate runs, using \\
SSTs/SICE from CMIP5 runs \\
NCAR-CAM3.5 & SSTs/SICE from AR4 CCSM3 simulations (historical and SRES 2000 commitment, B1, A1B, \\
NCAR-CAM5.1 & and A2 for RCP 2.6, 4.5, 6.0, and 8.5, respectively) \\
STOC-HadAM3 & Decadal mean SST/Sea ice from fully coupled CESM-CAM5 model simulation for CMIP5 \\
UM-CAM & Same as HadGEM2 \\
& Same as HadGEM2
\end{tabular}

http://cf-pcmdi.llnl.gov) compliant names whenever available.

Not every model performed all simulations, even the primary ones. The overall availability of results for each model and each simulation is shown in Table 2. Data are currently archived at the British Atmospheric Data Centre (see http://badc.nerc.ac.uk), with a data access policy providing one year of access to participating groups only, followed by general public access to be granted no later than 31 July 2013.

\section{Model description}

In this section, we provide an overview of the 16 models that participated in ACCMIP simulations. In addition to these, the CSIRO-Mk3.6 CCM (Rotstayn et al., 2012) provided a limited set of diagnostics and is included in the aerosol analysis of Shindell et al. (2012a). Also, results from the TM5 model (Huijnen et al., 2010) are used in Stevenson et al. (2012). The overview discusses the main aspects of relevance to chemistry and atmospheric chemical composition. A more extensive description of each model is available as Supplement.

\subsection{General discussion}

The participating models are listed in Table 3. Of those, two are identified as Chemistry Transport Models (CTMs, i.e. driven by externally specified meteorological fields from analysis - CICERO-OsloCTM2, or climate model fields MOCAGE). Two others (UM-CAM and STOC-HadAM3) are referred to as Chemistry-General Circulation Models (CGCMs): they provide both prognostic meteorological and chemical fields, but chemistry does not affect climate. All other models are identified as Chemistry Climate Models (CCMs): in this case, simulated chemical fields (in addition to water vapour) are used in the radiation calculations and hence give a forcing on the general circulation of the atmosphere. Aerosol indirect effects are available in all classes of models.

In several cases, different models share many aspects: UM-CAM and Had-GEM2 use different dynamical cores, but share many parameterizations such as convection and the boundary layer scheme. On the other hand, UM-CAM and STOC-HadAM3 share the same dynamical core. A high degree of similarity is also found in GISS-E2-R and GISSE2-R-TOMAS (different aerosol scheme; we will use the terminology GISS-E2s when common characteristics are discussed) and NCAR-CAM3.5 and CESM-CAM-Superfast (different chemistry scheme). Also, NCAR-CAM3.5 and NCAR-CAM5.1 share the same dynamical core and several physics parameterizations but differ in their representation of clouds, radiation and boundary-layer processes; these models can be considered as distinct. 
Table 3. Continued.

\begin{tabular}{|c|c|c|}
\hline Model & $\begin{array}{l}\text { Composition-Radiation } \\
\text { Coupling }\end{array}$ & Photolysis scheme \\
\hline CESM-CAM-Superfast & $\begin{array}{l}\text { Online } \mathrm{H}_{2} \mathrm{O}, \mathrm{O}_{3}, \mathrm{SO}_{4} ; \text { offline } \mathrm{O}_{2}, \mathrm{CO}_{2}, \\
\mathrm{~N}_{2} \mathrm{O}, \mathrm{CH}_{4}, \mathrm{CFC} 11, \mathrm{CFC} 12, \mathrm{BC}, \mathrm{OC}, \\
\text { dust, sea salt }\end{array}$ & $\begin{array}{l}\text { Look-up table with correction for modeled clouds, } \\
\text { stratospheric } \mathrm{O}_{3} \text { and surface albedo, not aerosols. }\end{array}$ \\
\hline CICERO-OsloCTM2 & No coupling $(\mathrm{CTM})$ & $\begin{array}{l}\text { Online using the Fast-J2 (Wild et al., 2000; Bian and } \\
\text { Prather, 2002); accounts for modeled } \mathrm{O}_{3} \text {, clouds, sur- } \\
\text { face albedo and aerosols }\end{array}$ \\
\hline CMAM & $\begin{array}{l}\text { Online } \mathrm{O}_{3}, \mathrm{H}_{2} \mathrm{O} \text {; offline } \mathrm{CO}_{2}, \mathrm{CH}_{4} \text {, } \\
\mathrm{N}_{2} \mathrm{O}, \mathrm{CFC}-11 \text { and CFC-12 }\end{array}$ & $\begin{array}{l}\text { Look-up table depending on modeled strat. } \mathrm{O}_{3} \text { and sur- } \\
\text { face albedo; correction for clouds (follows Chang et al., } \\
\text { 1987) }\end{array}$ \\
\hline EMAC & $\begin{array}{l}\text { Online } \mathrm{O}_{3}, \mathrm{H}_{2} \mathrm{O}, \mathrm{SO}_{4}, \mathrm{CH}_{4}, \mathrm{CFCs} ; \text { cli- } \\
\text { matological aerosols }\end{array}$ & $\begin{array}{l}\text { Online calculations of photolysis rate coefficients (J- } \\
\text { values) using cloud water and ice content, cloudiness } \\
\text { and climatological aerosol (Jöckel et al., 2006) }\end{array}$ \\
\hline GEOSCCM & $\begin{array}{l}\text { online } \mathrm{H}_{2} \mathrm{O}, \mathrm{O}_{3}, \mathrm{~N}_{2} \mathrm{O}, \mathrm{CH}_{4}, \text { CFC- } \\
11, \mathrm{CFC}-12, \mathrm{HCFC}-22 \text {; offline aerosols }\end{array}$ & $\begin{array}{l}\text { Online (FastJX); accounts for clouds, strat } \mathrm{O}_{3} \text {, and } \\
\text { albedo; uses offline aerosols from GOCART }\end{array}$ \\
\hline GFDL-AM3 & $\begin{array}{l}\text { Online } \mathrm{H}_{2} \mathrm{O}, \mathrm{O}_{3}, \mathrm{SO}_{4}, \mathrm{BC} / \mathrm{OC}, \mathrm{SOA} \text {, } \\
\text { sea salt, dust; offline } \mathrm{CH}_{4}, \mathrm{CFCs}, \mathrm{N}_{2} \mathrm{O} \text {, } \\
\mathrm{CO}_{2}\end{array}$ & $\begin{array}{l}\text { Look-up table, based on TUV (v4.4); frequencies ad- } \\
\text { justed for modeled clouds, strat. } \mathrm{O}_{3} \text {, and surface albedo, } \\
\text { not for aerosols }\end{array}$ \\
\hline GISS-E2-R(-TOMAS) & $\begin{array}{l}\text { Online } \mathrm{H}_{2} \mathrm{O}, \mathrm{O}_{3}, \mathrm{SO}_{4}, \mathrm{BC} / \mathrm{OC} \text {, sea salt, } \\
\text { dust, } \mathrm{NO}_{3} \text {; offline/online } \mathrm{CH}_{4} \text { for his- } \\
\text { torical/future; offline } \mathrm{CO}_{2}, \mathrm{~N}_{2} \mathrm{O}, \mathrm{CFC} \text {; }\end{array}$ & $\begin{array}{l}\text { Online (Fast-J2 scheme); accounts for modeled clouds, } \\
\text { strat. } \mathrm{O}_{3} \text {, aerosols, surface albedo }\end{array}$ \\
\hline HadGEM2 & $\begin{array}{l}\text { Online tropospheric } \mathrm{O}_{3}, \mathrm{CH}_{4}, \mathrm{H}_{2} \mathrm{O} \text {, } \\
\mathrm{SO}_{4}, \mathrm{BC}, \mathrm{OC} \text {, dust; offline CFCs, } \mathrm{N}_{2} \mathrm{O} \text {, } \\
\text { strat } \mathrm{O}_{3}\end{array}$ & $\begin{array}{l}\text { Look-up table (Law and Pyle, 1993); no correction for } \\
\text { modeled fields }\end{array}$ \\
\hline LMDzORINCA & $\begin{array}{l}\text { Offline } \mathrm{CO}_{2}, \mathrm{CH}_{4}, \mathrm{CFC} \text { and } \mathrm{N}_{2} \mathrm{O} \text {; no } \\
\text { aerosol interactions }\end{array}$ & $\begin{array}{l}\text { Look-up table, based on TUV (v4.1); frequencies ad- } \\
\text { justed for modeled clouds, strat. } \mathrm{O}_{3} \text {, and surface albedo, } \\
\text { not for aerosols }\end{array}$ \\
\hline MIROC-CHEM & $\begin{array}{l}\text { Online } \mathrm{H}_{2} \mathrm{O}, \mathrm{O}_{3}, \mathrm{SO}_{4}, \mathrm{BC} / \mathrm{OC} \text {, sea salt, } \\
\text { dust, } \mathrm{CFCs}, \mathrm{N}_{2} \mathrm{O} \text {; offline } \mathrm{CH}_{4}, \mathrm{CO}_{2}\end{array}$ & $\begin{array}{l}\text { Online coupled with radiation code considering gas } \\
\text { absorption and cloud/aerosol/surface albedo, based on } \\
\text { Landgraf and Crutzen (1998) }\end{array}$ \\
\hline MOCAGE & No coupling (CTM) & $\begin{array}{l}\text { Look-up table with correction for modeled clouds, } \\
\text { stratospheric } \mathrm{O}_{3} \text { and surface albedo, not aerosols }\end{array}$ \\
\hline NCAR-CAM3.5 & $\begin{array}{l}\text { Online } \mathrm{H}_{2} \mathrm{O}, \mathrm{O}_{3}, \mathrm{SO}_{4}, \mathrm{BC} / \mathrm{OC} \text {, SOA, } \\
\text { sea salt, dust, } \mathrm{CH}_{4}, \mathrm{CFCs}, \mathrm{N}_{2} \mathrm{O} \text {; offline } \\
\mathrm{CO}_{2}\end{array}$ & $\begin{array}{l}\text { Look-up table with correction for modeled clouds, } \\
\text { stratospheric } \mathrm{O}_{3} \text { and surface albedo, not aerosols }\end{array}$ \\
\hline NCAR-CAM5.1 & $\begin{array}{l}\text { Online } \mathrm{H}_{2} \mathrm{O} \text {, aerosol with water uptake } \\
\text { by } \kappa \text {-Kohler }\end{array}$ & NA \\
\hline STOC-HadAM3 & No coupling $(\mathrm{CTM})$ & $\begin{array}{l}\text { 1-D, two-stream model (Hough, 1988). Uses climato- } \\
\text { logical ozone above tropopause and modelled ozone be- } \\
\text { low }\end{array}$ \\
\hline UM-CAM & $\begin{array}{l}\text { Offline } \mathrm{O}_{3} \text { (CMIP5 database), } \mathrm{CH}_{4} \text {, } \\
\mathrm{CO}_{2}, \mathrm{~N}_{2} \mathrm{O}, \mathrm{CFCs}\end{array}$ & $\begin{array}{l}\text { Look-up table (Law and Pyle, 1993); no correction for } \\
\text { modeled fields }\end{array}$ \\
\hline
\end{tabular}

Different grid structures are used for the horizontal discretization. EMAC and CICERO-OsloCTM2 are based on a quadratic Gaussian grid of approximately $2.8^{\circ}$, i.e. a spherical truncation of T42. CMAM is also a spectral model and was run at T47, though uses a regular grid $(3.8 \times 3.8$ degree $)$ for physical parameterizations. GFDL-AM3 has a horizontal domain consisting of a $6 \times 48 \times 48$ cubed sphere-grid, with the grid size varying from $163 \mathrm{~km}$ (at the 6 corners of the cubed sphere) to $231 \mathrm{~km}$ (near the centre of each face). All remaining models use a regular latitude-longitude grid ranging from $1.25^{\circ} \times 1.875^{\circ}\left(\right.$ HadGEM2) to $2.5^{\circ} \times 3.75^{\circ}($ STOC-Hadam 3 and UM-CAM). While the physics calculations in STOCHadAM3 are performed at $2.5^{\circ} \times 3.75^{\circ}$, this model uses a Lagrangian chemical transport scheme, after which the fields are remapped onto a $5^{\circ} \times 5^{\circ}$ grid for output. While the horizontal resolutions are relatively homogeneous, the models have a greater range of vertical extent and resolution. Top levels range from $50 \mathrm{hPa}$ (STOC-HadAM3) to $0.0081 \mathrm{hPa}$ (CMAM), with a number of levels varying from 19 (LMDzORINCA, STOC-HadAM3 and UM-CAM) to 90 (EMAC) (Fig. 4). 
Table 3. Continued.

\begin{tabular}{|c|c|c|}
\hline Model & Species simulated & Stratospheric Ozone \\
\hline CESM-CAM-Superfast & $\begin{array}{l}16 \text { gas species; interactive sulfate; no aerosol indirect } \\
\text { effects }\end{array}$ & Linearized ozone chemistry \\
\hline CICERO-OsloCTM2 & $\begin{array}{l}93 \text { gas species; } \mathrm{BC}, \mathrm{OC} \text {, sea salt, nitrate, sulfate, sec- } \\
\text { ondary organic aerosols }\end{array}$ & Synoz. $\mathrm{O}_{3}$ flux $450 \mathrm{Tgyr}^{-1}$ \\
\hline CMAM & $\begin{array}{l}42 \text { gas-phase species; No prognostic aerosols; specified } \\
\text { monthly average sulphate distribution for hydrolysis re- } \\
\text { actions }\end{array}$ & Full stratospheric chemistry \\
\hline EMAC & $\begin{array}{l}96 \text { gas-phase species, } 8 \text { additional species and } 41 \text { reac- } \\
\text { tions for liquid phase chemistry, no prognostic aerosol }\end{array}$ & Full stratospheric chemistry \\
\hline GEOSCCM & No aerosols, 120 gas-phase species & Full stratospheric chemistry \\
\hline GFDL-AM3 & $\begin{array}{l}81 \text { gas species; interactive } \mathrm{SO}_{\mathrm{x}}, \mathrm{BC} / \mathrm{OC}, \mathrm{SOA}, \mathrm{NH}_{3} \text {, } \\
\mathrm{NO}_{3} \text {, sea salt and dust; AIE included }\end{array}$ & Full stratospheric chemistry \\
\hline $\begin{array}{l}\text { GISS-E2-R } \\
\text { (-TOMAS) }\end{array}$ & $\begin{array}{l}51 \text { gas species; interactive sulfate, } \mathrm{BC}, \mathrm{OC} \text {, sea salt, } \\
\text { dust, } \mathrm{NO}_{3}, \mathrm{SOA} \text {; AIE included }\end{array}$ & Full stratospheric chemistry \\
\hline HadGEM2 & $\begin{array}{l}\text { Interactive } \mathrm{SO}_{4}, \mathrm{BC}, \mathrm{OC} \text {, sea salt, dust; AIE included. } \\
41 \text { species }\end{array}$ & $\begin{array}{l}\text { Offline stratospheric } \mathrm{O}_{3} \text { from } \\
\text { CMIP5 dataset }\end{array}$ \\
\hline LMDzORINCA & 82 gas species; no aerosols & $\begin{array}{l}\text { Offline stratospheric } \mathrm{O}_{3} \text { (climatol- } \\
\text { ogy from Li and Shine, 1995) }\end{array}$ \\
\hline MIROC-CHEM & $\begin{array}{l}58 \text { gas species; } \mathrm{SO}_{4}, \mathrm{BC}, \mathrm{OC} \text {, sea salt, dust; AIE in- } \\
\text { cluded }\end{array}$ & Full stratospheric chemistry \\
\hline MOCAGE & 110 gas species; no aerosols & Full stratospheric chemistry \\
\hline NCAR-CAM3.5 & $\begin{array}{l}117 \text { gas species; } \mathrm{BC}, \mathrm{OC}, \mathrm{SO}_{4}, \mathrm{NO}_{3}, \mathrm{SOA} \text {, dust, sea } \\
\text { salt }\end{array}$ & Full stratospheric chemistry \\
\hline NCAR-CAM5.1 & $\begin{array}{l}\text { DMS, } \mathrm{SO}_{2}, \mathrm{H}_{2} \mathrm{SO}_{4} \text { gas } \mathrm{SO}_{4}, \mathrm{BC}, \mathrm{SOA}, \mathrm{POA} \text {, sea salt, } \\
\text { and mineral dust aerosol internally mixed in } 3 \text { modes } \\
\text { with predicted number. AIE included. }\end{array}$ & $\begin{array}{l}\text { Prescribed distributions } \\
\text { NCAR-CAM3.5 }\end{array}$ \\
\hline STOC-HadAM3 & 65 gas phase species, $\mathrm{SO}_{4}$ and $\mathrm{NO}_{3}$ aerosol & $\begin{array}{l}\text { Offline stratospheric } \mathrm{O}_{3} \text { from } \\
\text { CMIP5 dataset }\end{array}$ \\
\hline UM-CAM & 60 gas phase species; no aerosols & $\begin{array}{l}\text { Offline stratospheric ozone from } \\
\text { CMIP5 dataset }\end{array}$ \\
\hline
\end{tabular}

\subsection{Deep convection}

In CCMs, various convection schemes are used: Tiedtke (1989) for EMAC, Gregory and Rowntree (1990) for Had-GEM2 and GISS-E2s, Arakawa-Schubert for GEOSCCM (Moorthi and Suarez, 1992), Emanuel (1991, 1993) for LMDzORINCA, and Zhang and McFarlane (1995) for CMAM, CESM-CAM-Superfast, NCAR-CAM3.5 and NCAR-CAM5.1.

In CGCMs, the convective diagnostics are obtained from the driving GCM, following Gregory and Rowntree (1990) in the case of UM-CAM and Collins et al. (2002; this model uses convective mass fluxes from HadAM3 to derive the probability of a parcel being subject to convective transport) in the case of STOC-HadAM3. CICERO-OsloCTM2 uses the convective mass flux (based on the Tiedtke, 1989 parameterization) from the ECMWF Integrated Forecast System (IFS). MOCAGE re-computes its own distribution of convection using Bechtold et al. (2001).

All these parameterizations are based on the mass-flux approach. However, Scinocca and McFarlane (2004) showed that even with a single scheme, there is a wide variation in behaviour depending on details such as closure of the cloudbase mass flux. Furthermore, implementation details in the transport of tracers will make the impact of convection different between models. The variations in representing deep convection as well as any shallow convection processes can therefore be a source of inter-model differences with respect to the vertical transport of chemical constituents, especially in the tropical regions. Unfortunately, very few models provided convective mass flux as output and a more complete discussion cannot take place without additional simulations.

\subsection{Wet and dry deposition}

Wet removal and deposition of chemical species depends on their solubility, itself defined in terms of their Henry's law effective coefficient, for gases and their hygroscopicity for aerosols. Removal by both large-scale and convective precipitation is taken into account. Many models follow a first-order loss parameterization (e.g. Giannakopoulous et al., 1999). In Oslo-CTM2 only rainout, i.e. scavenging in 
Table 3. Continued.

\begin{tabular}{|c|c|}
\hline Model & NMHCs \\
\hline CESM-CAM-Superfast & Isoprene only \\
\hline CICERO-OsloCTM2 & $\begin{array}{l}\mathrm{C}_{2} \mathrm{H}_{4}, \mathrm{C}_{2} \mathrm{H}_{6}, \mathrm{C}_{3} \mathrm{H}_{6}, \mathrm{C}_{3} \mathrm{H}_{8}, \mathrm{C}_{4} \mathrm{H}_{10} \text { (butanes }+ \text { pentanes), } \mathrm{C}_{6} \mathrm{H}_{14} \text {, hexanes }+ \text { higher alkanes), } \\
\mathrm{CH}_{2} \mathrm{O}, \mathrm{CH}_{3} \mathrm{CHO} \text { (other alkanals), ACETONE (ketones), AROMATICS (benzene + toluene + } \\
\text { trimethylbenzenes + xylene +other_ aromatics), isoprene, terpenes }\end{array}$ \\
\hline CMAM & None \\
\hline EMAC & Up to isoprene \\
\hline GEOSCCM & $\begin{array}{l}\text { MEK ( }>\mathrm{C} 3 \text { ketones), } \mathrm{PRPE} \text { (propene and } \geq \mathrm{C} 3 \text { alkenes), } \mathrm{C}_{2} \mathrm{H}_{6}, \mathrm{C}_{3} \mathrm{H}_{8}, \mathrm{CH}_{2} \mathrm{O}, \mathrm{ALK} 4(\geq \mathrm{C} 4 \\
\text { alkanes), acetaldehyde, isoprene, monoterpene, biogenic propene }\end{array}$ \\
\hline GFDL-AM3 & $\begin{array}{l}\text { Monoterpenes, } \mathrm{C}_{2} \mathrm{H}_{4}, \mathrm{C} 2 \mathrm{H} 5 \mathrm{OH}, \mathrm{C}_{2} \mathrm{H}_{6}, \mathrm{C}_{3} \mathrm{H}_{6}(\mathrm{C}>3 \text { alkenes }), \mathrm{C}_{3} \mathrm{H}_{8}, \mathrm{C}_{4} \mathrm{H}_{10}(\mathrm{C}>4 \text { alkanes }), \\
\mathrm{CH}_{2} \mathrm{O}, \mathrm{CH}_{3} \mathrm{COCH}_{3}, \mathrm{CH}_{3} \mathrm{OH} \text {, and isoprene }\end{array}$ \\
\hline $\begin{array}{l}\text { GISS-E2-R } \\
\text { (-TOMAS) }\end{array}$ & $\begin{array}{l}\text { Isoprene, terpernes, alkenes (propene, other alkenes and alkynes, ethene), paraffin (propane, } \\
\text { pentanes, butanes, hexanes and higher alkanes, ethane, ketones) }\end{array}$ \\
\hline HadGEM2 & Up to propane \\
\hline LMDzORINCA & $\begin{array}{l}\text { Isoprene, Terpenes, } \mathrm{CH}_{3} \mathrm{OH}, \mathrm{C}_{2} \mathrm{H}_{5} \mathrm{OH}, \mathrm{C}_{2} \mathrm{H}_{6}, \mathrm{C}_{3} \mathrm{H}_{8}, \mathrm{ALKAN}, \mathrm{C}_{2} \mathrm{H}_{4}, \mathrm{C}_{3} \mathrm{H}_{6}, \mathrm{C}_{2} \mathrm{H}_{2}, \text { ALKEN, } \\
\text { AROM, } \mathrm{CH}_{2} \mathrm{O}, \mathrm{CH}_{3} \mathrm{CHO}, \mathrm{CH}_{3} \mathrm{COCH}_{3}, \mathrm{MEK}, \mathrm{MVK}, \mathrm{CH}_{3} \mathrm{COOH}\end{array}$ \\
\hline MIROC-CHEM & $\begin{array}{l}\mathrm{C}_{2} \mathrm{H}_{6}, \mathrm{C}_{3} \mathrm{H}_{8}, \mathrm{C}_{2} \mathrm{H}_{4}, \mathrm{C}_{3} \mathrm{H}_{6} \text {, acetone, } \mathrm{CH}_{3} \mathrm{OH}, \mathrm{HCHO}, \mathrm{CH}_{3} \mathrm{CHO} \text {, a lumped species (ONMV), } \\
\text { isoprene and terpenes }\end{array}$ \\
\hline MOCAGE & $\begin{array}{l}\text { Benzene, butanes, esters, ethane, ethene, ethers, ethyne, HCHO, hexanes and higher alkanes, } \\
\text { isoprene, ketones, other alkanals, other alkenes and alkynes, other aromatics, other VOC, pen- } \\
\text { tanes, propane, propene, toluene, trimethyl benzene, xylene, terpenes, alcohols, acids }\end{array}$ \\
\hline NCAR-CAM3.5 & $\mathrm{C}_{2} \mathrm{H}_{4}, \mathrm{PAR}$, OLE, toluene, $\mathrm{CH}_{2} \mathrm{O}, \mathrm{CH}_{3} \mathrm{CHO}$, isoprene, $\mathrm{C}_{10} \mathrm{H}_{16}$ \\
\hline NCAR-CAM5.1 & $\begin{array}{l}\text { SOA gas from emitted monoterpene, isoprene, soluene, big alkanes, big alkenes with prescribed } \\
\text { yields }\end{array}$ \\
\hline STOC-HadAM3 & $\begin{array}{l}\mathrm{CH}_{3} \mathrm{OH}, \mathrm{C}_{2} \mathrm{H}_{6}, \mathrm{C}_{3} \mathrm{H}_{8}, \mathrm{NC}_{4} \mathrm{H}_{10}, \mathrm{C}_{2} \mathrm{H}_{4}, \mathrm{C}_{3} \mathrm{H}_{6}, \mathrm{HCHO}, \mathrm{CH}_{3} \mathrm{CHO}, \mathrm{MVK} \text {, acetone, toluene, } \\
\text { o-xylene, isoprene (plus some others) }\end{array}$ \\
\hline UM-CAM & $\mathrm{C}_{2} \mathrm{H}_{6}, \mathrm{C}_{3} \mathrm{H}_{8}, \mathrm{HCHO}, \mathrm{CH}_{3} \mathrm{CHO}, \mathrm{CH}_{3} \mathrm{COCH}_{3}$, isoprene \\
\hline
\end{tabular}

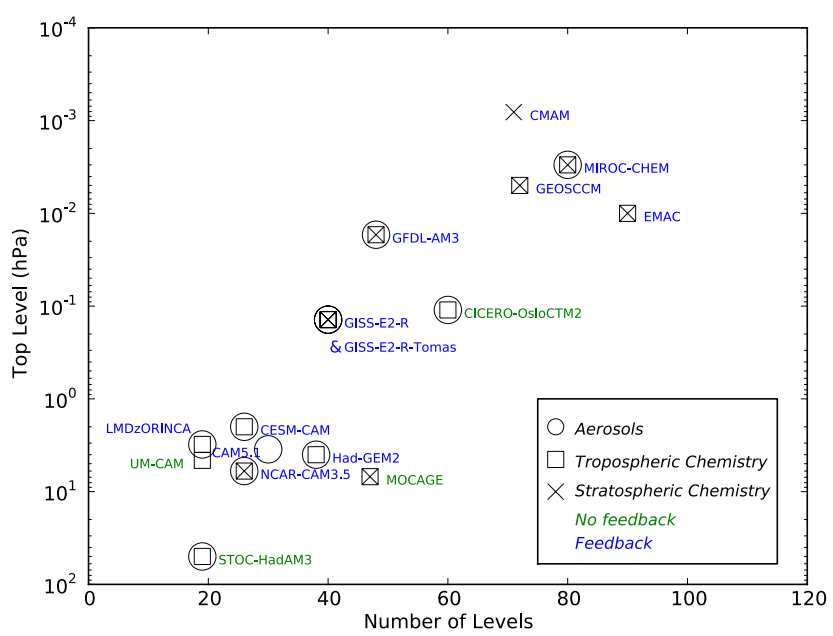

Fig. 4. Vertical extent and number of levels for each ACCMIP model. In addition the representation of tropospheric chemistry, stratospheric chemistry and tropospheric aerosols is indicated by the combination of symbols. Note that, for clarity, CESM-CAM has been displaced upward but should be overlapping NCARCAM3.5. Feedback refers to the impact of explicitly resolved chemical species on radiation and therefore the simulated climate (see text for details). clouds, is represented, while all the other models also include washout, i.e. scavenging below clouds. Moreover, GISS-E2s describe detrainment (of mass and chemical species) and evaporation from convective plumes (Shindell et al., 2001).

Dry deposition velocities are commonly represented using the resistance approach (e.g. Wesely, 1989), which takes into account land-cover type, boundary-layer height and physi$\mathrm{cal} / \mathrm{chemical}$ properties of the given species. Deposition velocities are calculated through this approach in all models, with various degrees of complexity and averaging of underlying vegetation distributions (UM-CAM specifies the deposition velocities offline). For aerosols, dry deposition includes gravitational settling, and for some models the additional complexity of size-resolved deposition processes are used (in GISS-E2-R-TOMAS and NCAR-CAM5.1).

\subsection{Natural emissions}

While all anthropogenic and biomass burning emissions were specified (see Sect. 2.1), each modelling group independently specified their natural emissions (note: in all models but GISS-E2-R and LMDzORINCA, methane is treated as a specified surface layer concentration condition and therefore described in Sect. 3.5). In particular, isoprene (and other biogenic volatile organic compounds, VOCs) and $\mathrm{NO}_{\mathrm{x}}$ soil 
emissions depend on meteorological and surface conditions (e.g. Guenther et al., 2006; Yienger and Levy, 1995), and these effects have been accounted for differently between models. GEOSCCM has online emissions both for soil $\mathrm{NO}_{\mathrm{x}}$ and isoprene and other biogenic VOCs, whereas EMAC has online isoprene and soil NO emissions, and fixed biogenic emissions for $\mathrm{CO}$ and other VOCs. GFDL-AM3, LMDzORINCA, MOCAGE, NCAR-CAM3.5 and UM-CAM prescribe fixed biogenic emissions, usually based on presentday estimates. GISS-E2-R, STOC-HadAM3 and CICEROOsloCTM2 have interactive isoprene but fixed soil $\mathrm{NO}_{\mathrm{x}}$. This generates a relatively large range in soil $\mathrm{NO}_{\mathrm{x}}$ emissions, ranging from $2.7 \mathrm{Tg} \mathrm{N} \mathrm{yr}^{-1}$ (GISS-E2-R) to $9.3 \mathrm{Tg} \mathrm{N} \mathrm{yr}^{-1}$ (CMAM) for present-day (see Table 2 in Stevenson et al., 2012) This range is similar, albeit somewhat smaller than the values of Steinkamp and Lawrence $\left(2011 ; 8.6 \mathrm{Tg} \mathrm{N} \mathrm{yr}^{-1}\right.$ for their geometry mean estimate) or Jaeglé et al. (2005;

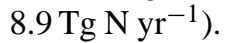

For the lightning $\mathrm{NO}_{\mathrm{x}}$ emissions, most models use the parameterization of Price and Rind (1992) (or similar), which is based solely on the simulated convective activity. EMAC's parameterization is based on the relation between updraft velocity (and the associated cloud electrification) and flash frequency (Grewe et al., 2001). Some models scale lightning $\mathrm{NO}_{\mathrm{x}}$ fluxes to reach a preset global magnitude value (specific to each model and usually chosen for present-day only). All these allow for some coupling between climate and lightning. To the contrary, GEOSCCM uses a fixed lightning emissions at $5 \mathrm{Tg} \mathrm{N} \mathrm{yr}^{-1}$ following the climatological distribution from Price and Rind (1992). Note however that lightning $\mathrm{NO}_{\mathrm{x}}$ emissions were erroneously high in MIROCCHEM and erroneously low in HadGEM2. This all leads to a spread of 1.2 to $9.7 \mathrm{Tg} \mathrm{N} \mathrm{yr}^{-1}$ for the 2000 conditions (Fig. 3; also Table 2 in Stevenson et al., 2012), with little variations over the historical period. Note that this range is significantly wider than the $6 \pm 2 \mathrm{Tg} \mathrm{N} \mathrm{yr}^{-1}$ satellite-based estimate of Martin et al. (2007). All these variations (with the addition of other biogenic and oceanic sources) lead to the spread in total emissions displayed in Fig. 3 (also see Table S2).

\subsection{Boundary conditions}

As mentioned in Sect. 2, monthly mean SSTs and SICs were prescribed, except for GISS-E2s and LMDzORINCA in which case the SSTs/SICs are calculated online during the transient simulation. Many models used the decadal means (usually from a single ensemble member of multiple transient simulations) from a companion CMIP5 simulation (i.e. CESM-CAM Superfast, CMAM, GFDL-AM3, HadGEM2, LMDzORINCA MIROC-CHEM, MOCAGE, NCAR-CAM5.1, STOC-HadAM3 and UM-CAM). Of these, HadGEM2, STOC-HadAM3 and UM-CAM use the same SSTs and SICs from HadGEM2. EMAC used SSTs/SICs from CMIP5 simulations carried out with the CMCC Climate
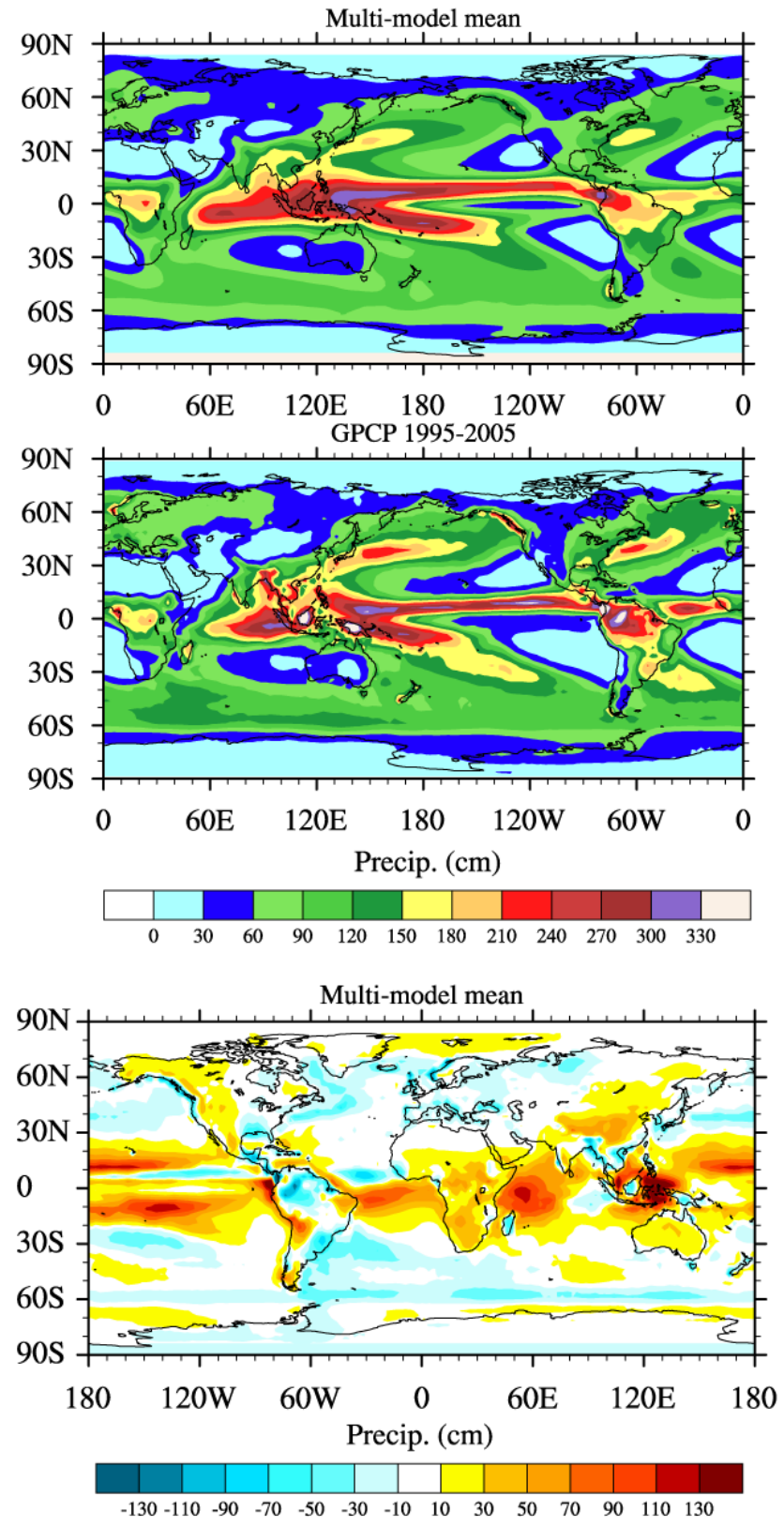

Fig. 5. Top: multi-model annual precipitation from the 2000 time slice experiment. Middle: annual precipitation from GPCP. Bottom: difference (multi-model mean minus GPCP).

Model, also based on ECHAM5, but with differences in resolution and shortwave radiation (Cagnazzo et al., 2007).

Some models used the previous AR4 simulations, applying an approximate correspondence between RCPs and SRES scenarios (GEOSCCM, NCAR-CAM3.5; see Lamarque et al., 2011). Finally, the CICERO-OsloCTM2 model used analysis data for year 2006 from ECMWF IFS analysis for all experiments. 
Methane concentration (from Meinshausen et al., 2011, see Fig. 2) is prescribed at the surface (bottom layer or two layers, with or without a specified latitudinal gradient) in many models. It is prescribed over the whole atmosphere in CESM-CAM-Superfast and NCAR-CAM5.1 (using the NCAR-CAM3.5 distribution) and in STOC-HadAM3 and UM-CAM. Only LMDzORINCA uses methane emissions for historical and future simulations, while GISS-E2s use emissions only for future simulations. In both cases, those simulations include climate-dependent wetland emissions.

\subsection{Photolysis}

Photolysis rates in the models are computed with off-line (look-up table) or online methods. In the offline case, the look-up table contains values of photolysis rates for every photolytic reaction in the model over a range of pressures, solar zenith angles, overhead ozone columns and temperatures. These pre-computed values are filled once at the start of the model run, and then interpolated at any time and grid point for the specific conditions in time and space. This method can be directly applied with a modulation to take into account local clouds and surface albedo (CESMCAM-Superfast, CMAM, GFDL-AM3, LMDz-OR-INCA, MOCAGE, NCAR-CAM3.5 and NCAR-CAM5.1), while two models (HadGEM2, UM-CAM) do not apply such corrections. A drawback of this approach is the lack of coupling with the simulated aerosols.

Online photolysis schemes (CICERO-Oslo-CTM2, EMAC, GEOSCCM, GISS-E2s, MIROC-CHEM and STOC-HadAM3), solve the radiative transfer equation at each time-step and gridpoint, depending on local temperature, pressure, aerosol content, cloudiness, surface albedo, overhead ozone column and solar zenith angle.

Note that a limited intercomparison of some stratospheric (and therefore of limited relevance to this study) photolysis rates is available in Chapter 6 of SPARC CCMVal (2010). Standard deviation on the order of 10-20\% are common for the major photolysis rates, although this could become larger in the troposphere due to interferences by clouds and aerosols.

\subsection{Chemistry}

\subsubsection{Tropospheric gas-phase and aerosols}

Apart from NCAR-CAM5.1 (which is aerosol-oriented with minimal chemistry; X. Liu et al., 2012), all models participating in ACCMIP simulate, at a minimum, gaseous tropospheric chemistry (Fig. 4). However, chemistry is represented to various degrees of complexity: from 16 species in CESM-CAM-Superfast to 120 in GEOSCCM. This range is mostly due to the less or more detailed representation of nonmethane hydrocarbon (NMHCs) chemistry (or lack thereof in the case of CMAM) for each model, with each having
Table 4. Globally-averaged mean bias and root-mean square difference for annual mean $700 \mathrm{hPa}$ temperature $(\mathrm{K})$ and precipitation $\left(\mathrm{mm} \mathrm{day}^{-1}\right)$. Note that because of their very similar climate diagnostics, results from GISS-E2-R and GISS-E2-R-TOMAS are combined.

\begin{tabular}{lccccc}
\hline & \multicolumn{2}{c}{ T 700 hPa (K) } & & \multicolumn{2}{c}{ Precip (mm day $\left.{ }^{-1}\right)$} \\
\cline { 2 - 3 } \cline { 6 - 7 } Model & Bias & RMSD & & Bias & RMSD \\
\hline CESM-CAM-Superfast & -0.06 & 0.94 & & 0.19 & 1.25 \\
CICERO & 0.14 & 0.47 & & 0.48 & 1.01 \\
CMAM & -0.10 & 1.14 & & 0.28 & 1.41 \\
EMAC & -0.62 & 1.11 & & N/A & N/A \\
GEOSSCM & -0.77 & 1.22 & & 0.17 & 1.11 \\
GFDL-AM3 & -1.40 & 1.71 & & 0.31 & 1.34 \\
GISS-E2-R(-TOMAS) & -0.36 & 1.03 & & 0.51 & 1.54 \\
HadGEM2 & -0.53 & 0.88 & & N/A & N/A \\
LMDzORINCA & N/A & N/A & & N/A & N/A \\
MIROC-CHEM & -1.53 & 2.22 & & 0.08 & 1.29 \\
MOCAGE & -0.99 & 1.48 & & -0.05 & 2.04 \\
NCAR-CAM3.5 & -1.03 & 1.33 & & 0.10 & 1.34 \\
NCAR-CAM5.1 & N/A & N/A & & N/A & N/A \\
STOC-HadAM3 & -1.41 & 1.74 & & 0.28 & 1.13 \\
UM-CAM & -1.53 & 1.83 & & 0.12 & 1.08 \\
Multi-Model mean & -0.78 & 0.91 & & 0.22 & 0.98 \\
\hline
\end{tabular}

its own lumping of NMHV emissions into species present in their chemical scheme. This is particularly important since it will automatically define the total amount of NMHC emissions released into the model atmosphere and NMHC reactivity as well as affect yields of radicals and intermediate product species such as formaldehyde and glyoxal. In terms of NMHC chemistry, the smallest representations are in CESM-CAM-Superfast (where only isoprene is taken into account) and in HadGEM2 which does not include isoprene (only non-methane hydrocarbons up to propane are considered). However, some simulations were also performed with HadGEM2-ExtTC (results of which are used only in Stevenson et al., 2012) which differ from HadGEM2 only by its extended chemistry scheme, including interactive biogenic NMHCs. Only GEOSCCM, GISS-E2-R, MOCAGE and CICERO-Oslo-CTM2 include the reaction of $\mathrm{HO}_{2}$ with $\mathrm{NO}$ to yield $\mathrm{HNO}_{3}$ (Butkovskaya et al., 2007). Due to uncertainties on this reaction (Sander et al., 2011), it is important to identify which models include it as it significantly impacts the response of the tropospheric composition to changes in $\mathrm{NO}_{\mathrm{x}}$ emissions (Søvde et al., 2011).

NCAR-CAM5.1 and GISS-E2-R-TOMAS have the most extensive description of aerosols. Aerosols in NCARCAM5.1 are represented by three internally-mixed lognormal modes (Aitken, accumulation, and coarse), with the total number and mass of each component (sulfate, organic carbon, black carbon, mineral dust and sea salt) predicted for each mode (X. Liu et al., 2012). The TOMAS model alone has 108 size-resolved aerosol tracers plus three bulk aerosolphase tracers. TOMAS predicts aerosol number and mass 


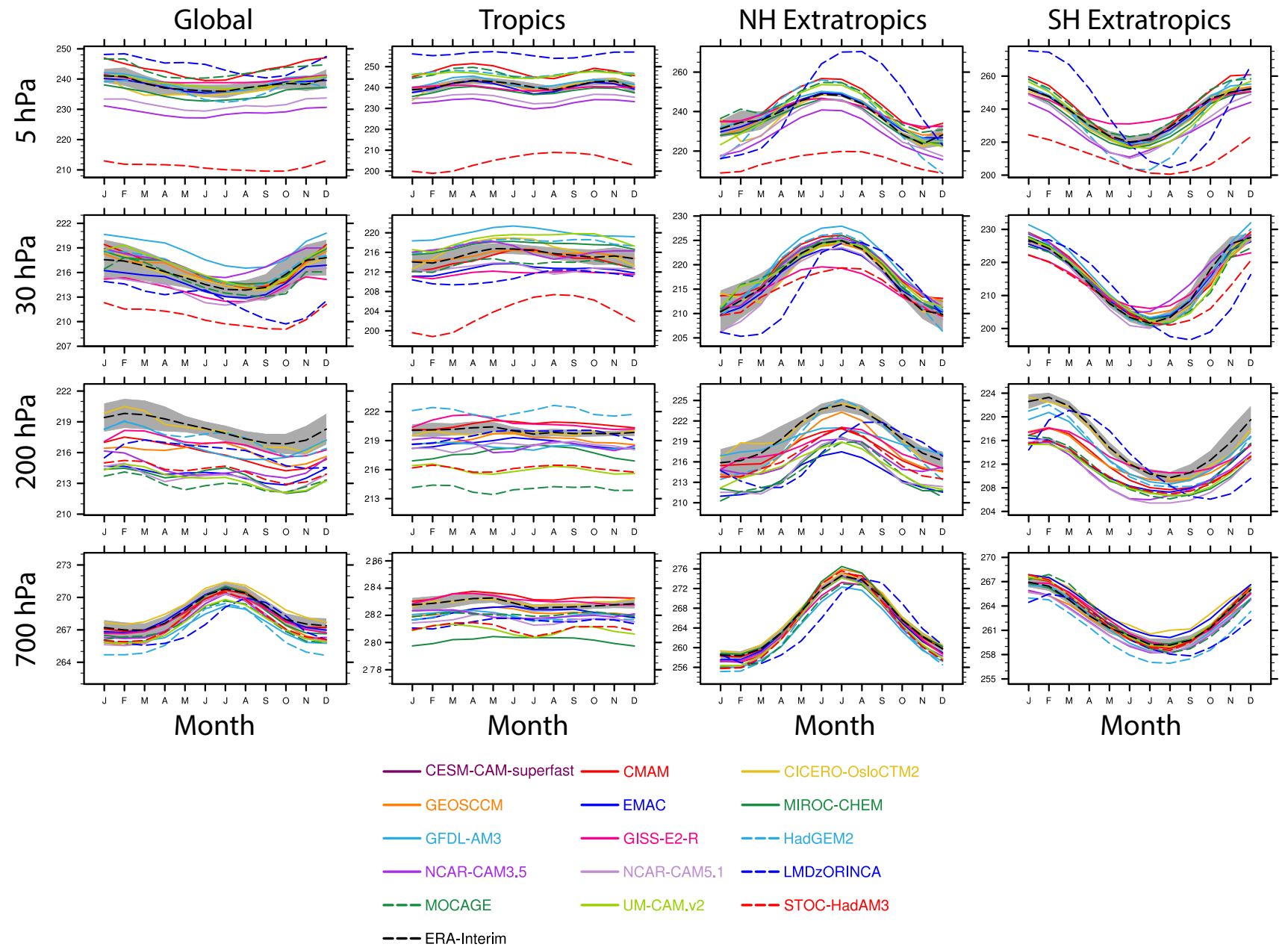

Fig. 6. Seasonal cycle of temperature $(\mathrm{K})$ at 4 pressure levels for all models and the ERA-Interim reanalysis.

size distributions by computing total aerosol number (i.e. 0th moment) and mass (i.e. 1st moment) concentrations for each species (sulfate, sea salt, internally mixed elemental carbon, externally mixed elemental carbon, hydrophilic organic matter, hydrophobic organic matter, mineral dust, aerosol-water) in 12-size bins ranging from $10 \mathrm{~nm}$ to $10 \mu \mathrm{m}$ in dry diameter, following Lee and Adams (2011). The LMDzORINCA model simulates the distribution of anthropogenic aerosols such as sulfates, black carbon, particulate organic matter, as well as natural aerosols such as sea salt and dust. The aerosol code keeps track of both the number and the mass of aerosols using a modal approach to treat the size distribution, which is described by a superposition of log-normal modes (Schulz et al., 1998; Schulz, 2007). All other models that include aerosols use the bulk approach (i.e. computing mass only, with a specified distribution and no representation of coagulation).

Heterogeneous reactions on tropospheric aerosols are described through a limited set of heterogeneous reactions (5 or fewer), except GISS-E2-R-TOMAS, which has none.
The aerosol indirect effects are represented in approximately half of the models (CICERO, GFDL-AM3, GISSE2s, HadGEM2, MIROC-CHEM and NCAR-CAM5.1).

\subsubsection{Stratospheric chemistry and ozone distribution}

Many models have a full representation of stratospheric ozone chemistry (Fig. 4), with the inclusion of ozonedepleting substances (containing $\mathrm{Br}$ and $\mathrm{Cl}$ ), and heterogeneous chemistry on polar stratospheric clouds. For the models without stratospheric chemistry, stratospheric ozone is specified in several ways. CESM-CAM-Superfast uses a linearized ozone chemistry parameterization (LINOZ, McLinden et al., 2000). CICERO-Oslo-CTM2 uses monthly model climatological values of ozone and nitrogen species, except in the 3 lowermost layers in the stratosphere (approximately $2.5 \mathrm{~km}$ ) where the tropospheric chemistry scheme is applied to account for photochemical $\mathrm{O}_{3}$ production in the lower stratosphere due to the presence of $\mathrm{NO}_{\mathrm{x}}, \mathrm{CO}$ and NMHCs (Skeie et al., 2011b). Had-GEM2s, STOC-HadAM3 and UM-CAM input their time-varying stratospheric ozone 

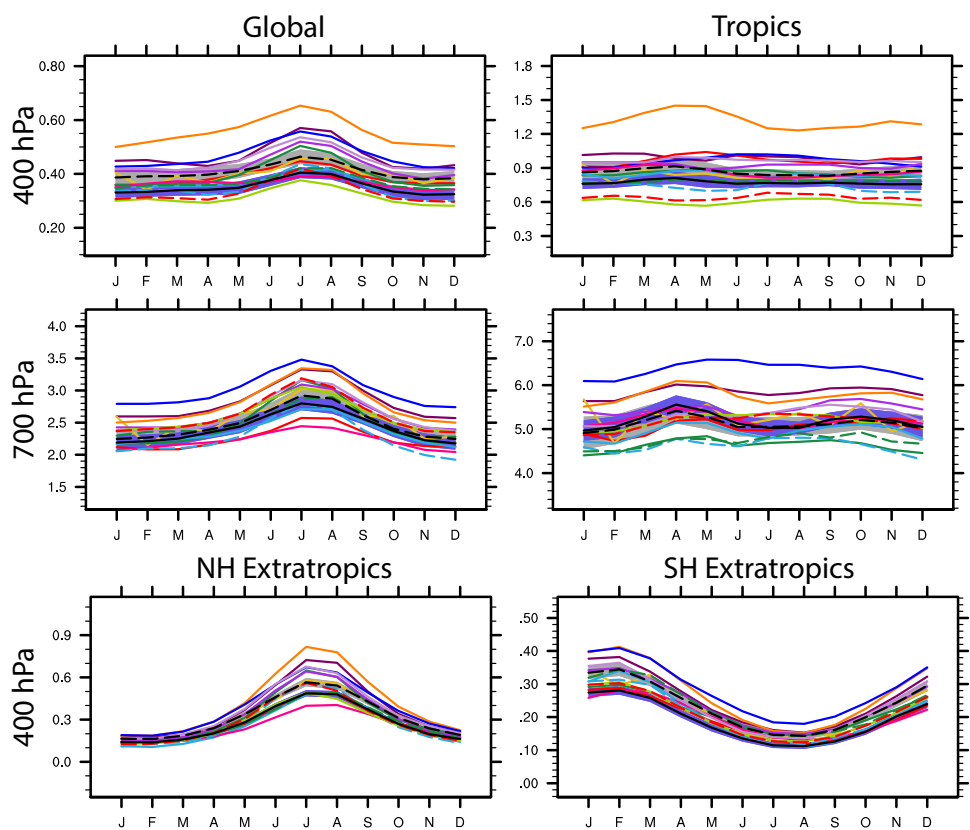

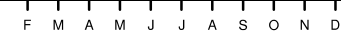

SH Extratropics
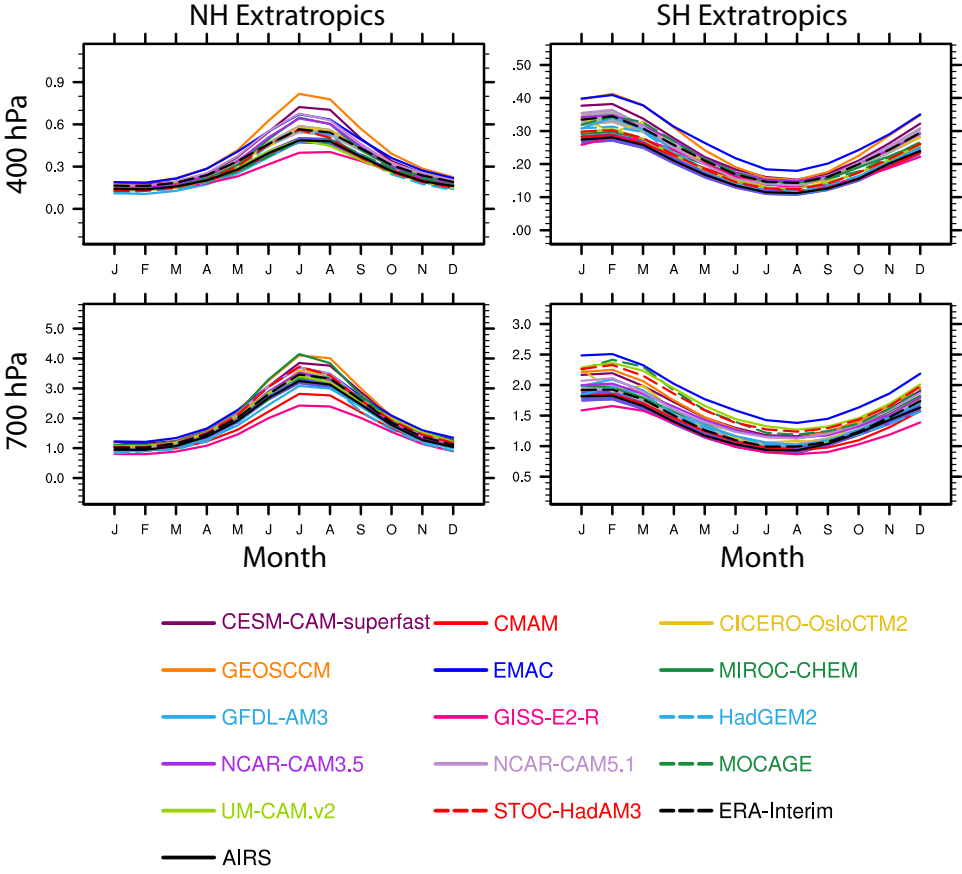

Fig. 7. Seasonal cycle of specific humidity $\left(\mathrm{g} \mathrm{kg}^{-1}\right)$; reanalysis data are from the ERA-Interim and AIRS are satellite retrievals (see text for details).

distribution from the CMIP5 database (Cionni et al., 2011). Finally, LMDzORINCA uses a constant (for all simulations) climatological values of stratospheric ozone ( $\mathrm{Li}$ and Shine, 1995). Note that changes in stratospheric ozone do affect photolysis in all other models but HadGEM2 and UM-CAM.

\subsection{Radiation coupling}

The composition-radiation coupling will depend on the simulated species. Most of the CCMs use their simulated distribution of water vapour and ozone to compute their direct radiative impact, except for HadGEM2 in which the online coupling is only applied in the troposphere, UMCAM which is forced by offline data, and LMDzORINCA which has no ozone coupling. The simulated methane distribution is used for radiation calculations in EMAC,
GEOSCCM, HadGEM2, GISS-E2s, MIROC-CHEM and NCAR-CAM3.5. When aerosols are prognostically calculated in the model (note that CESM-CAM-Superfast only simulates sulphate), they are all coupled to the radiation scheme. GEOSCCM and EMAC do not have an explicit aerosol description but they include in their computation of atmospheric heating profiles the radiative effect of aerosols taken from time-varying climatologies.

\section{Evaluation of present-day climate}

We present in this section an analysis and evaluation of selected climate diagnostics in the ACCMIP models. We focus on quantities that are directly relevant to chemistry modeling, namely precipitation, temperature, humidity and zonal wind. 


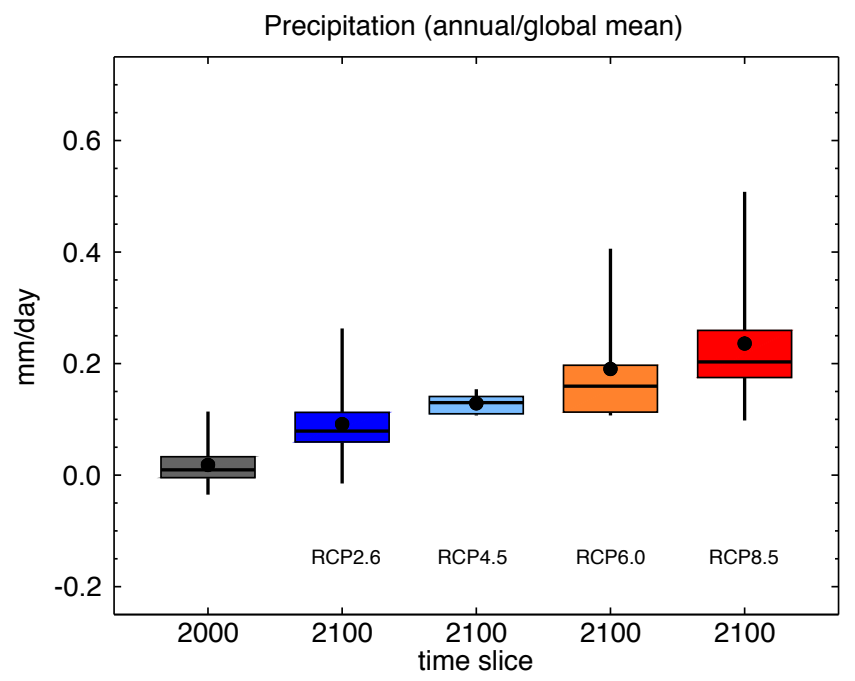

Fig. 8. Global annual mean precipitation change since 1850 . The multi-model mean is indicated by the solid black dot, the median by the solid black line, the $25-75 \%$ range by the extent of the colored box and the minimum/maximum by the extend of the whisker. Note the there is variation in the number of models between the various simulations (see Table 2).

In particular, temperature is analyzed at $700 \mathrm{hPa}$ since that is representative of the main location of the tropical methane loss (Spivakovsky et al., 2000). Also, we only discuss annual means since our main interest is on long-term changes.

When compared against the Global Precipitation Climatology Project (GPCP) climatology for 1995-2005 (Adler et al., 2003), the simulated annual mean precipitation tends to be higher than observed over the tropical regions (except for tropical South America) in all models (Figs. 5 and S1). While the multi-model model annual mean precipitation (Fig. 5) provides many similarities to the CMIP3 multimodel mean in Randall et al. (2007; see their Fig. 8.5), there is also considerable improvement over Indonesia and the continental outflows of Asia and North America. Many models still suffer from an overestimate of the precipitation over the Indian Ocean and over high topography, the latter a consequence of the fairly coarse resolution used in these models. Overall, models tend to exhibit a positive areaweighted global mean bias (MB) against GPCP, ranging from $0.08 \mathrm{~mm} \mathrm{day}^{-1}$ (NCAR-CAM3.5) to $0.51 \mathrm{~mm} \mathrm{day}^{-1}$ (GISSE2-R) except for MOCAGE $\left(-0.05 \mathrm{~mm} \mathrm{day}^{-1}\right)$, which also features a fairly large $\left(>1 \mathrm{~mm} \mathrm{day}^{-1}\right)$ area-weighted root mean square difference (RMSD) (see Table 4 and Fig. S1). This global positive bias in all models but MOCAGE will likely lead to an overestimate of the wet removal rate, especially for soluble chemical species in the tropical regions. However, a recent analysis of satellite-based precipitation estimates (Stephens et al., 2012) indicates that the GPCP precipitation rates over the oceans could be underestimated by approximately $10 \%$ or $0.3 \mathrm{~mm}$ day $^{-1}$ over the tropical

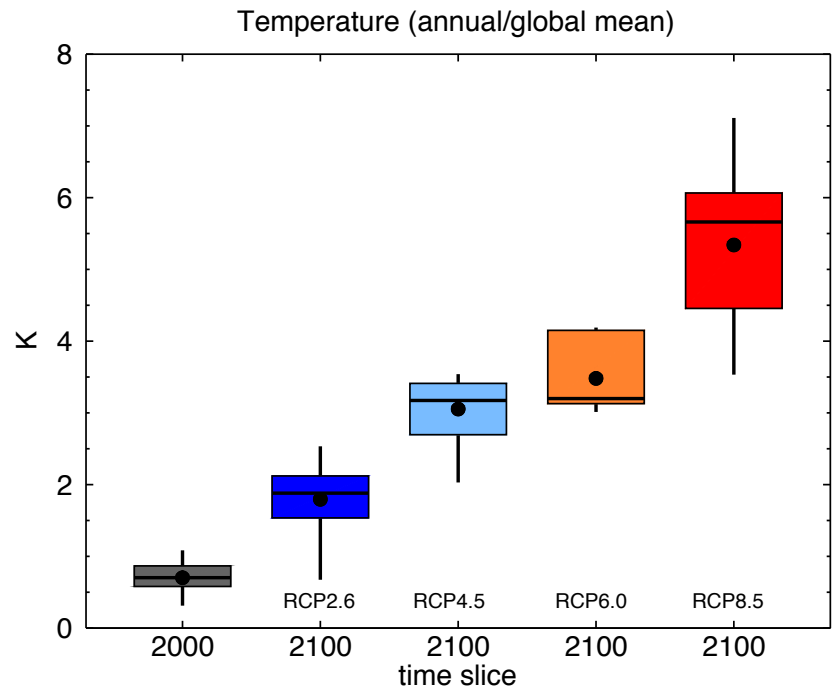

Fig. 9. Same as Fig. 8 but for $700 \mathrm{hPa}$ temperature change since 1850 .

oceans and more over the extra-tropical oceans. This means that many of the models are possibly providing reasonable large-scale precipitation rates (regional biases are doubtless still present), which would considerably reduce the possible biases on wet removal rates.

Similarly for temperature (Fig. 11), in the case of RCP2.6, the simulated change in CESM-CAM-Superfast shows an outlying negative bias, and the warming trend for NCARCAM3.5 is lower than any other model. There is much more inter-model agreement with the RCP8.5, with CESM-CAMSuperfast being showing the lowest temperature increase. Such inter-model variations will have consequences (in particular through the link of $\mathrm{OH}$ and specific humidity) for the interpretation of 21 st-century trends, especially methane lifetime. Indeed, as discussed in Voulgarakis et al. (2012), there is considerable spread in the estimated climate feedback on the methane lifetime $\left(0.33 \pm 0.13 \mathrm{yr} \mathrm{K}^{-1}\right)$. In the lower troposphere ( $700 \mathrm{hPa}$, approximately $3 \mathrm{~km}$, Table 4 and Fig. S2), the modeled temperatures tend to be biased cold compared to the European Centre for Medium-Range Weather Forecast Reanalysis Interim products (ERA-Interim, Dee et al., 2011; note that other reanalyses have very similar temperature distributions and therefore do not change the conclusions, not shown), with a MB ranging between $-1.5 \mathrm{~K}$ and close to $0 \mathrm{~K}$. At the global scale, the interannual variability in the ERA-Interim temperature at that pressure is on the order of $0.3 \mathrm{~K}$, meaning that many of the biases are significant (Fig. 6). CICERO-OsloCTM2 used fixed 2006 meteorology and therefore exhibits little difference with the climatology used for evaluation. The RMSD is larger than $1 \mathrm{~K}$ in all models. This negative bias is even more pronounced in the uppertroposphere and lower-stratosphere (200 hPa, Figs. 6 and S3), with biases as high as $6 \mathrm{~K}$ in all regions. Only CMAM has 

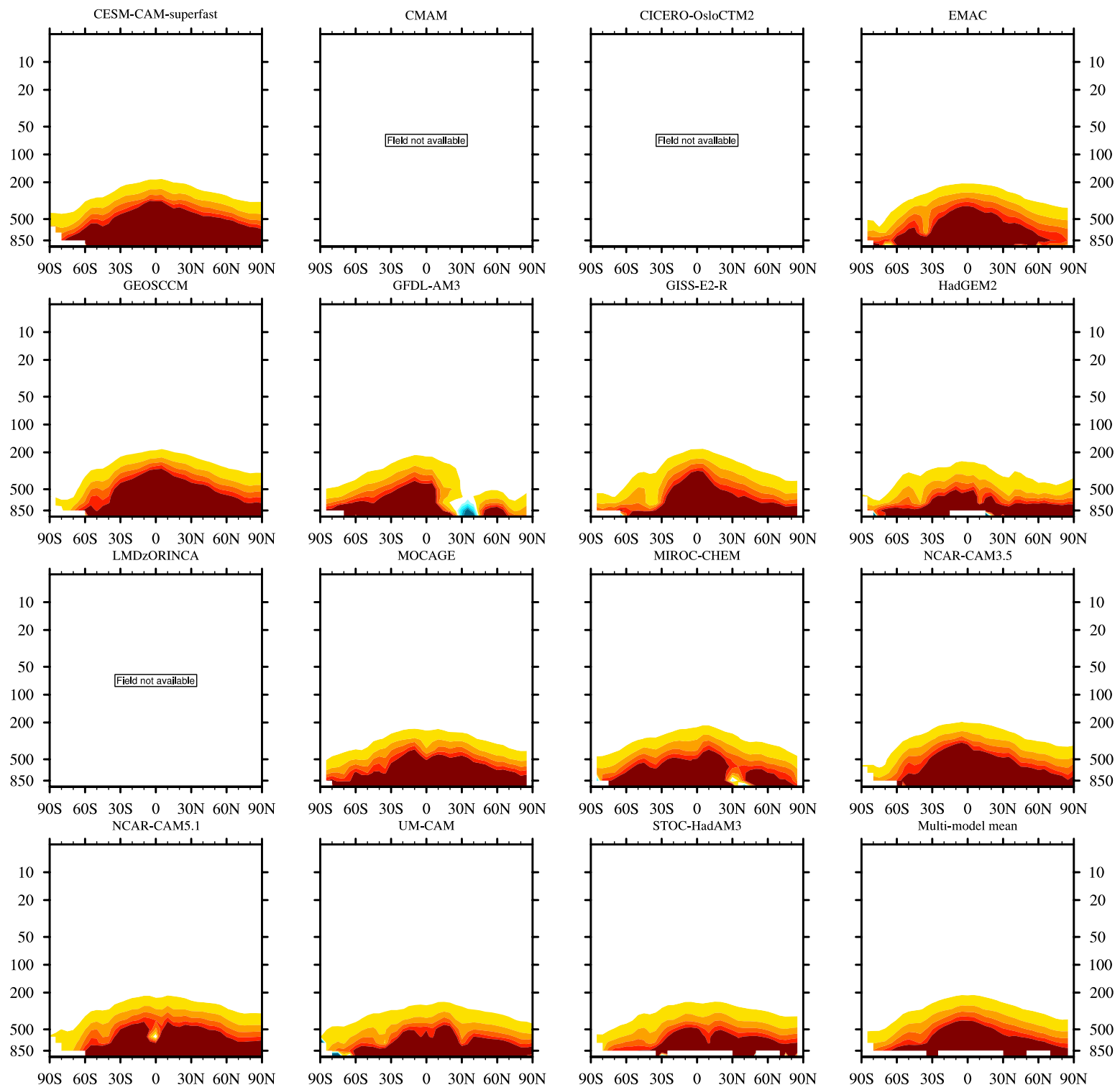

Fig. 10a. Difference 2000-1850 in annual and zonal mean specific humidity $\left(10^{-6} \mathrm{~kg} \mathrm{~kg}^{-1}\right)$.

a slight positive bias (1-2 K) in the tropical regions (Fig. 6). The temperatures biases are however smaller closer to the surface (see the $850 \mathrm{hPa}$ level in Fig. 6).

Specific humidity (using as references the ERA-Interim reanalysis and the Atmospheric InfraRed Sounder retrievals, AIRS, Divarkta et al., 2006) biases somewhat reflect the temperature biases (as illustrated by C. Liu et al., 2012), generally showing negative differences (Fig. S4), with a clear negative bias in the tropical regions in the troposphere for many models, associated with the aforementioned bias in the tropical precipitation. Many models also tend to exhibit a positive bias in specific humidity in the mid-troposphere $(400 \mathrm{hPa}$,
Fig. 7), especially when compared to AIRS. Biases in specific humidity in the tropical mid-troposphere will directly translate in biases in $\mathrm{OH}$, since $\left(\mathrm{O}^{1} \mathrm{D}+\mathrm{H}_{2} \mathrm{O}\right)$ is the primary source of $\mathrm{OH}$ in that region. The impact on ozone is however of variable sign depending on the chemical conditions (Jacob and Winner, 2009).

The position of the polar jet is important as it defines the extent of the polar vortex in which ozone depletion may occur. Many models tend to overestimate the strength of the Southern Hemisphere polar jet by $10-20 \mathrm{~m} \mathrm{~s}^{-1}$ compared to ERA-Interim (Fig. S5). This is also true of the Northern Hemisphere polar jet, but to a lesser extent. EMAC and 

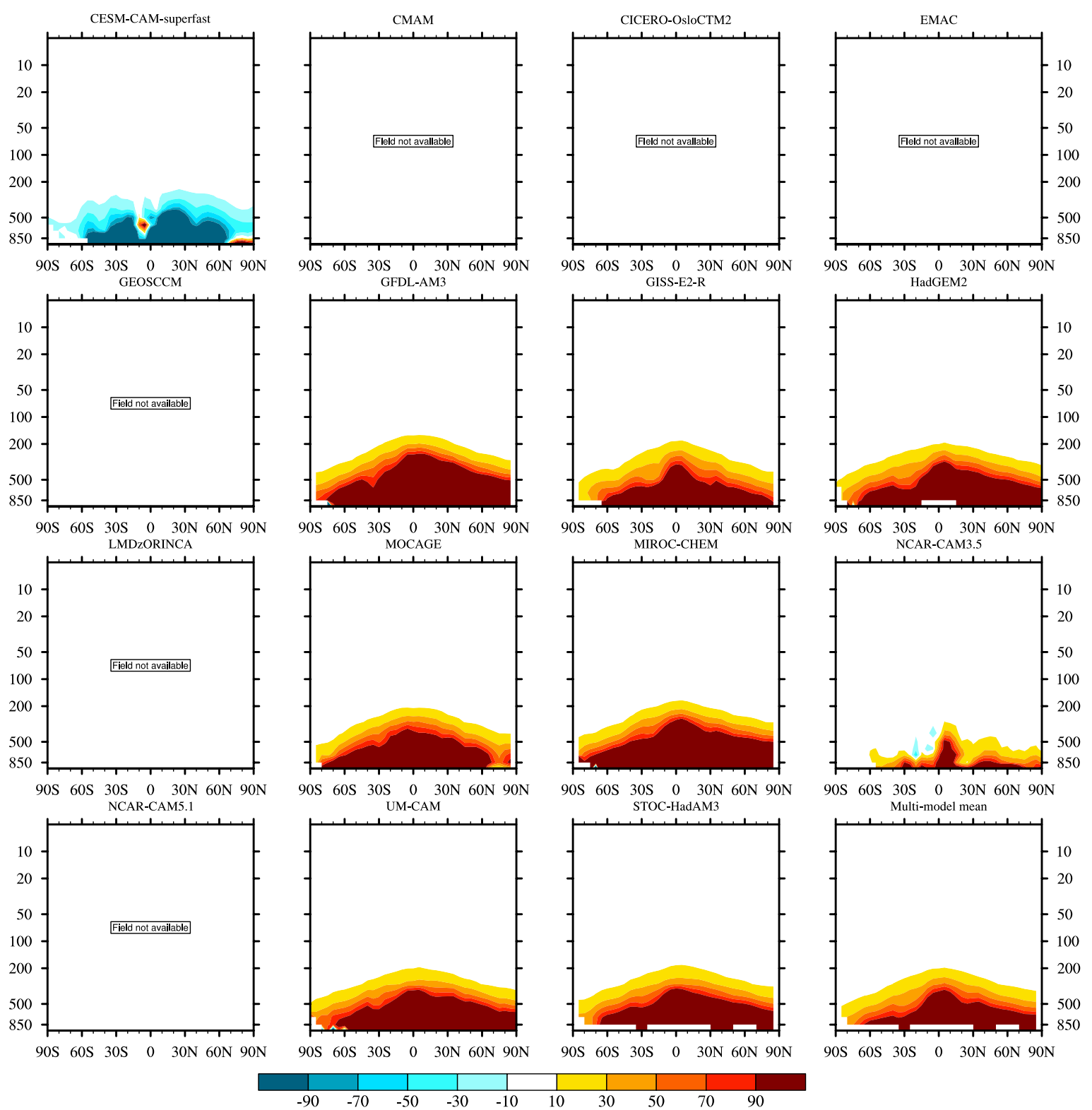

90S $60 \mathrm{~S} \quad 30 \mathrm{~S} \quad 0 \quad 30 \mathrm{~N} 60 \mathrm{~N} 90 \mathrm{~N}$

Fig. 10b. Difference 2100-2000 in annual and zonal mean specific humidity $\left(10^{-6} \mathrm{~kg} \mathrm{~kg}^{-1}\right)$ for RCP2.6. The CESM-CAM-Superfast results are spurious because of a mismatch in the SSTs used (see text for details).

GISS-E2s tend to show a negative bias in those regions. The biases in the Southern Hemisphere polar zonal wind distribution are strongly anti-correlated with the temperature biases in the same region (see Figs. S3 and S5); for example, CESM-CEM-Superfast poleward of $60^{\circ} \mathrm{S}$ and above $100 \mathrm{hPa}$. In the tropical lower stratosphere, there is a mixture of strong positive and negative biases, along with relatively small biases.

The mid-latitude jets are important as they define the extent of the tropical regions. Most models exhibit minor biases, although the CMAM and GISS-E2s models clearly overestimate its strength.

\section{Climate change as simulated in ACCMIP}

In this section, we document the simulated annual-mean changes in climate, over the simulated historical (18502000) and future (2000-2100) periods, emphasizing RCP2.6 and RCP8.5 for the latter since they represent the extremes of projected 2100 climate change under the RCPs. Results from CICERO-OsloCTM2 are ignored since they used the same meteorological fields for all time slices. The purpose of this section is to inter-compare model simulations to identify potential outliers. 


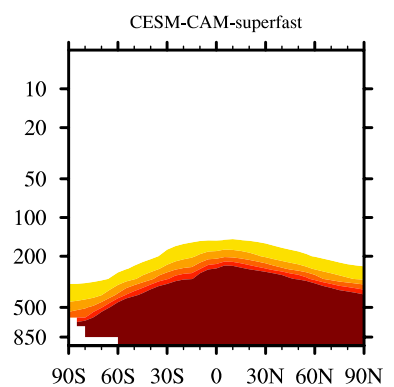

GEOSCCM
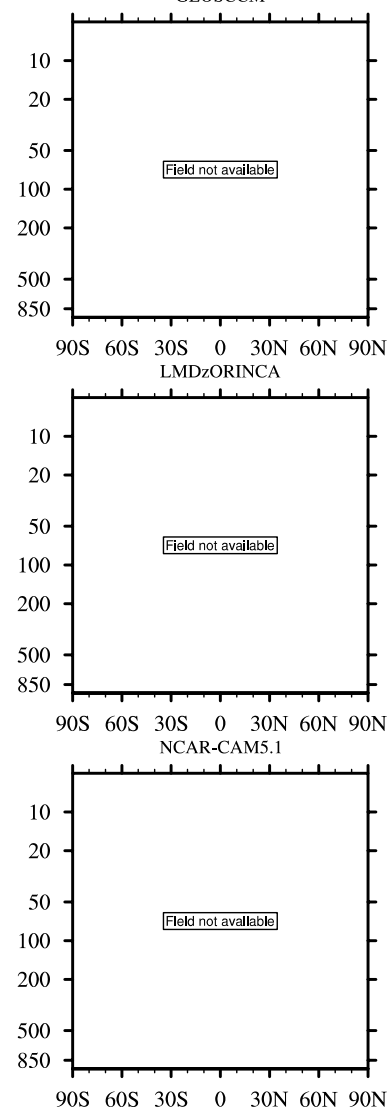

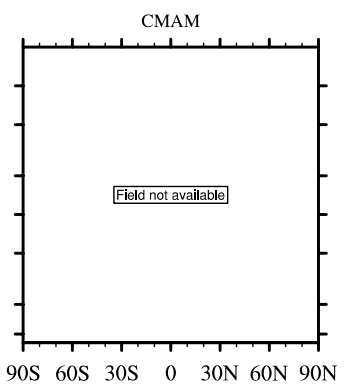

GFDL-AM3
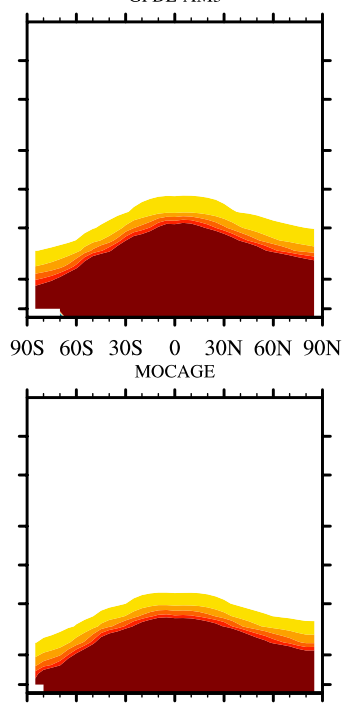

90S 60S 30S 0 30N $60 \mathrm{~N} \mathrm{90N}$ UM-CAM

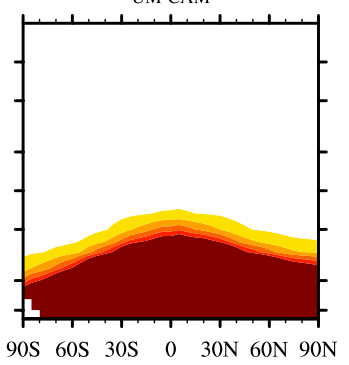

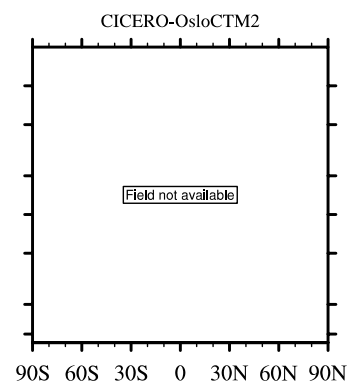

GISS-E2-R
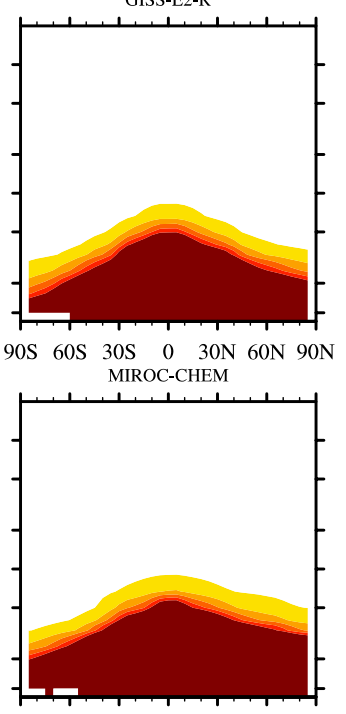

90S $60 \mathrm{~S} \quad 30 \mathrm{~S} \quad 0 \quad 30 \mathrm{~N} 60 \mathrm{~N} 90 \mathrm{~N}$ STOC-HadAM3

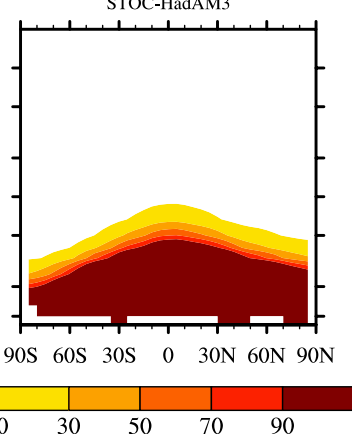

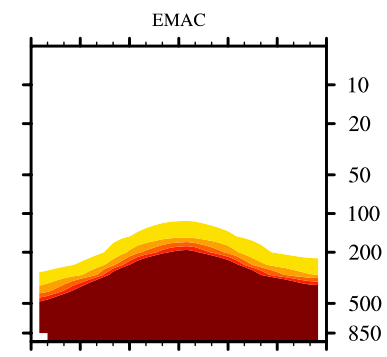

$90 \mathrm{~S} \quad 60 \mathrm{~S} \quad 30 \mathrm{~S} \quad 0 \quad 30 \mathrm{~N} 60 \mathrm{~N} 90 \mathrm{~N}$

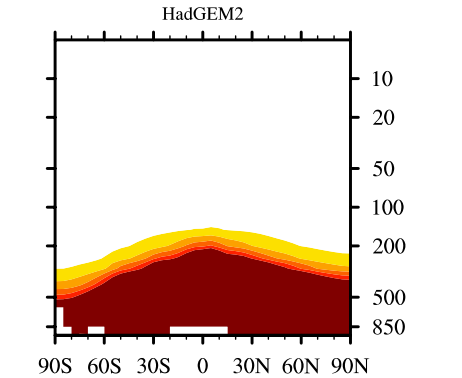

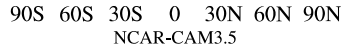

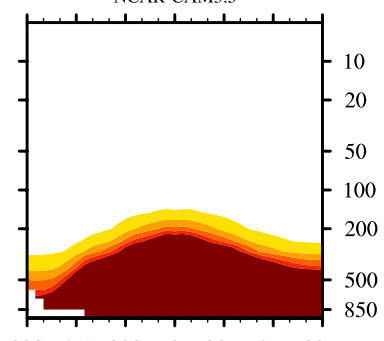

$90 \mathrm{~S} 60 \mathrm{~S} 30 \mathrm{~S} \quad 0 \quad 30 \mathrm{~N} 60 \mathrm{~N} 90 \mathrm{~N}$

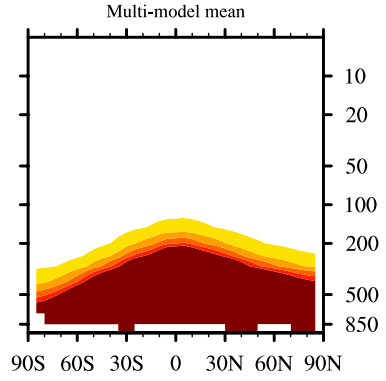

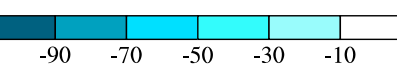



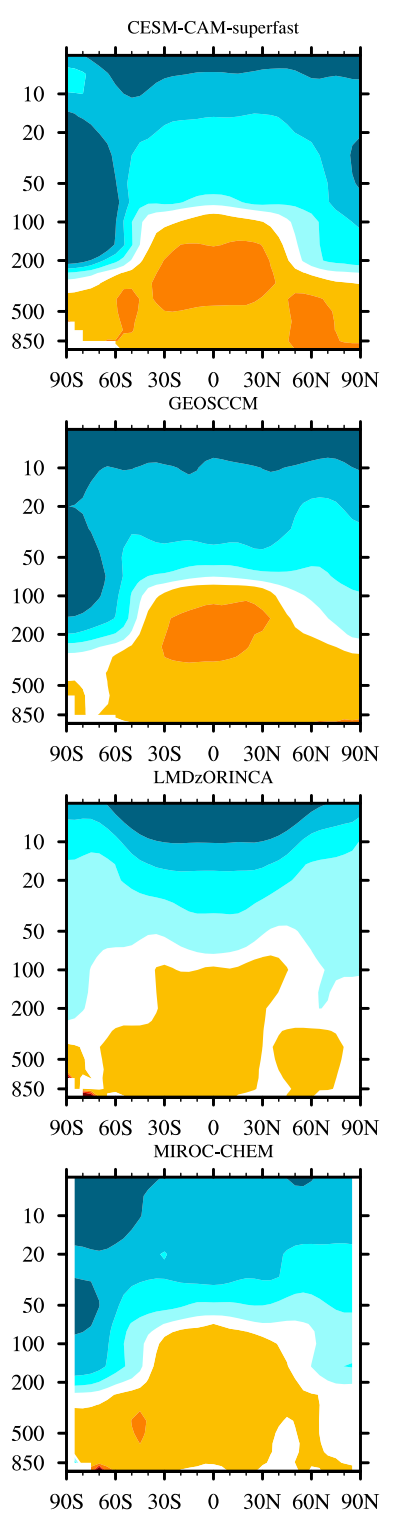

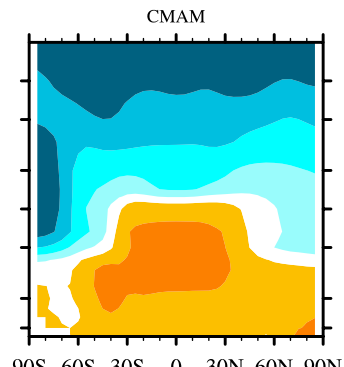

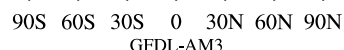
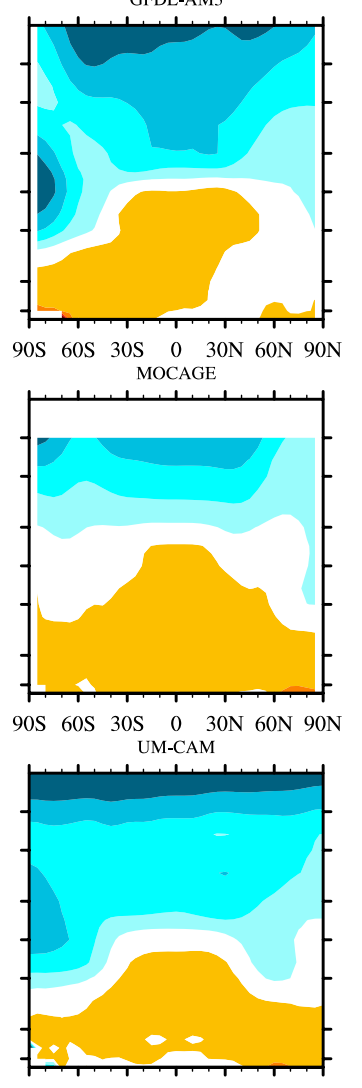

90S $60 \mathrm{~S} \quad 30 \mathrm{~S} \quad 0 \quad 30 \mathrm{~N} 60 \mathrm{~N} 90 \mathrm{~N}$
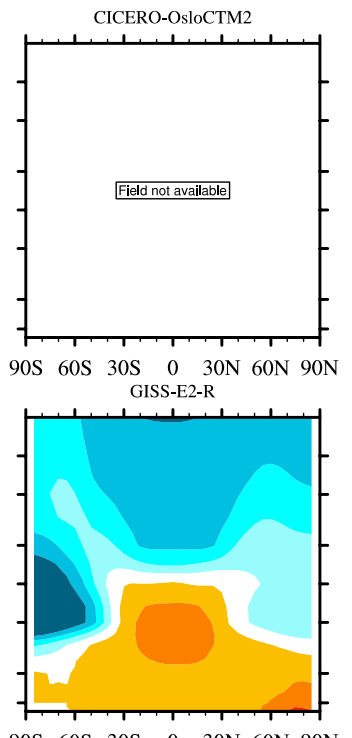

90S $60 \mathrm{~S} \quad 30 \mathrm{~S} \quad 0^{0} \quad 30 \mathrm{~N} 60 \mathrm{~N} 90 \mathrm{~N}$

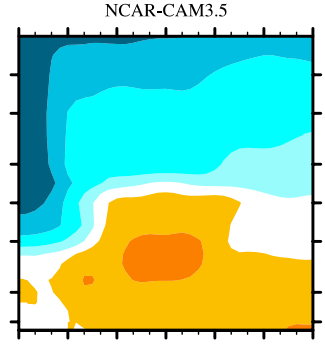

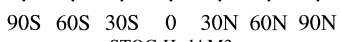
STOC-HadAM3

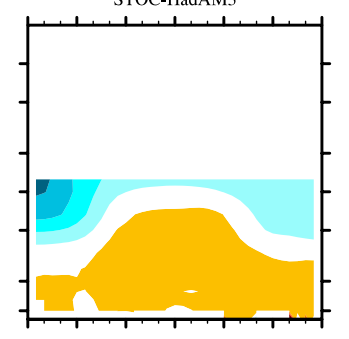

90S $60 \mathrm{~S} \quad 30 \mathrm{~S} \quad 0 \quad 30 \mathrm{~N} 60 \mathrm{~N} 90 \mathrm{~N}$
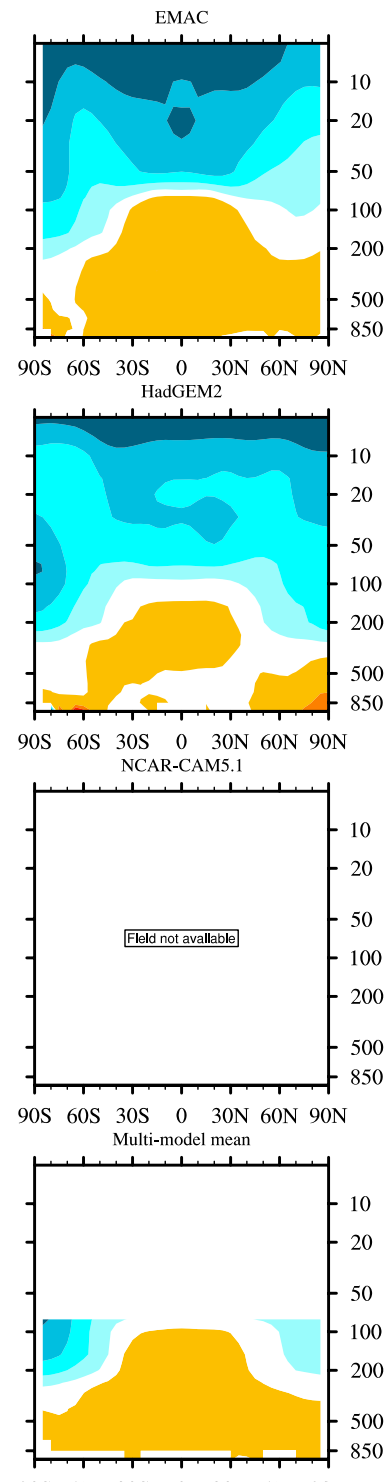

90S $60 \mathrm{~S} 30 \mathrm{~S} \quad 0 \quad 30 \mathrm{~N} 60 \mathrm{~N} 90 \mathrm{~N}$

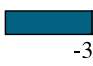

Fig. 11a. Difference 2000-1850 in annual and zonal mean temperature (K).

and between 2000 and 2100 in RCP8.5. The only slight difference is the presence of a negative change in the northern mid-latitudes specific humidity 1850-2000 change for the GFDL-AM3 simulation, and to a lesser extent MIROCCHEM. However, in the case of RCP2.6, this is not the case, with CESM-CAM-Superfast clearly an outlier with its simulated decrease in specific humidity between 2000 and 2100 . We also note that the RCP2.6 change for NCAR-CAM3.5 is considerably smaller than in the remaining models. Both issues are related to the use of the CCSM3 Commitment simulation to define the SSTs (see Lamarque et al., 2011 for more details), although it is exacerbated in CESM-CAM-Superfast by the fact that they used CCSM4 SSTs/SICs for their 2000 time slice; these are warmer than CCSM3 and therefore the specific humidity reflects an actual drop in temperature between year 2000 and year 2100 .

\section{Discussion and conclusions}

In this paper, we discuss and compare the 16 models that participated in the Atmospheric Chemistry and Climate Model Intercomparison Project (ACCMIP). We present the set of time slice experiments defined to document the changes 

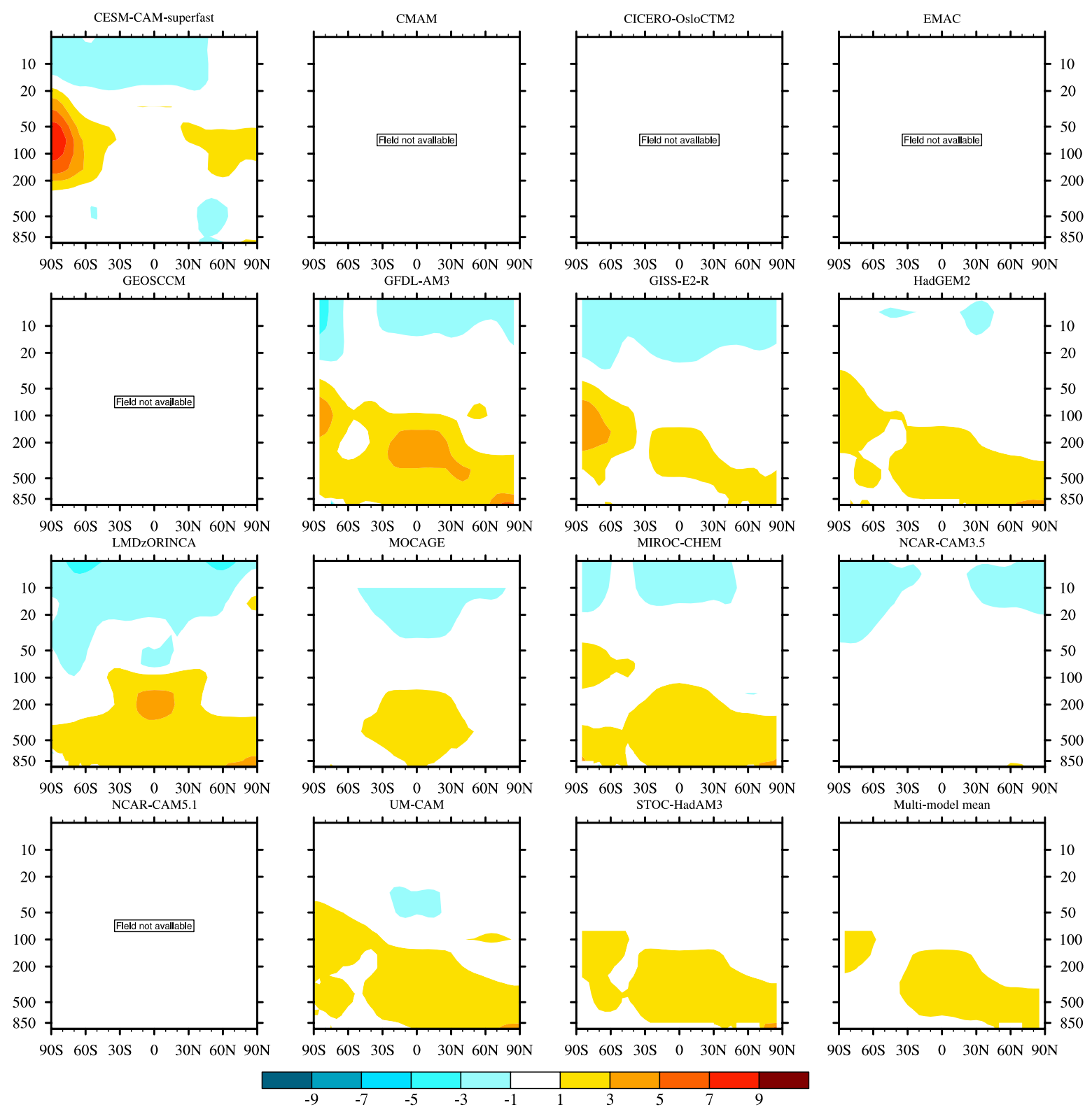

Fig. 11b. Difference 2100-2000 in annual and zonal mean temperature (K) for RCP2.6 (note expanded scale from a). The CESM-CAMSuperfast results are spurious because of a mismatch in the SSTs used (see text for details).

in atmospheric composition and in climate spanning 1850 to 2100 . In addition, sensitivity experiments were defined to understand the main drivers behind tropospheric ozone and methane lifetime changes. Since many ACCMIP models have companion CMIP5 simulations, the simulations performed for ACCMIP are intended to provide a description and understanding of the forcing driving the simulated climate change in the CMIP5 experiments and assess the strengths and weaknesses of the current generation of chemistry-climate models and/or their boundary conditions.
The addition of non-CMIP5 models provides an extended representation of the range of model results.

While the anthropogenic and biomass burning emissions were specified for all experiments, the analysis of the model setups indicates that the range of natural emissions is a significant source of model-to-model differences (Young et al., 2012). In particular, there is a range of representation of biogenic emissions (e.g. isoprene, soil $\mathrm{NO}_{\mathrm{x}}$ and methane) from explicitly specified to fully interactive with climate. The latter approach is clearly the path forward for the representation 


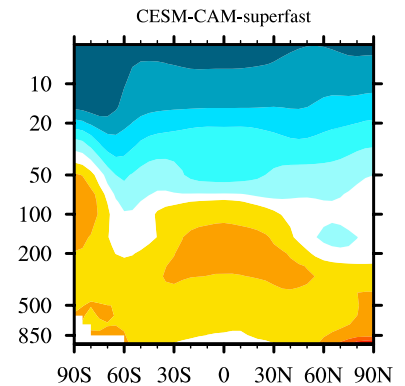

GEOSCCM

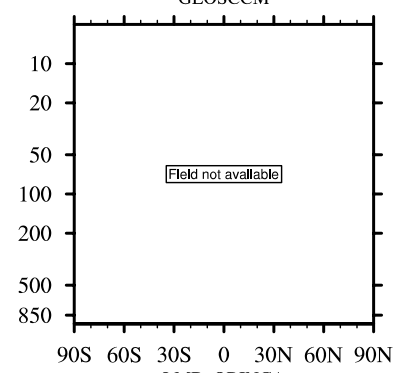

LMDzORINCA
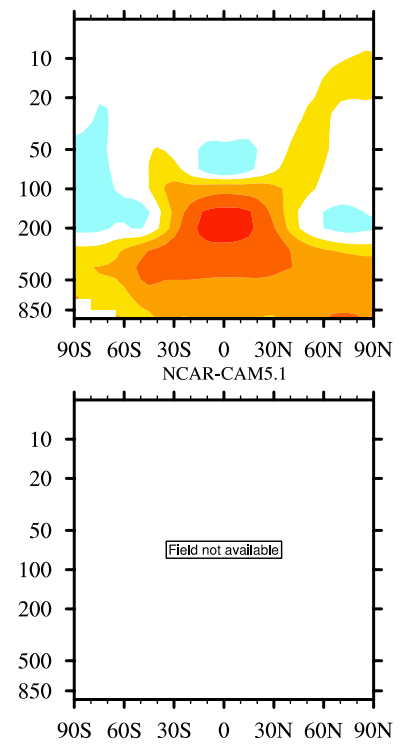

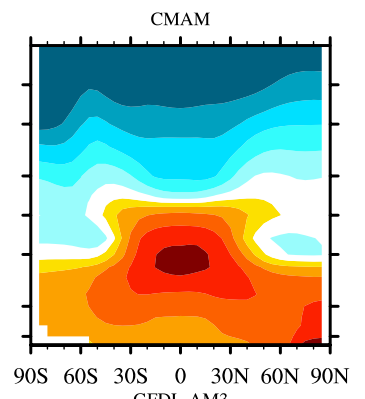

GFDL-AM3

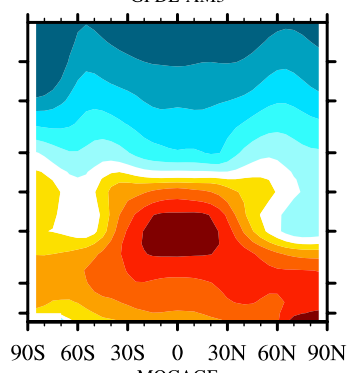

MOCAGE

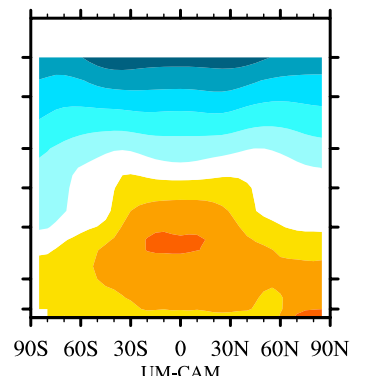

UM-CAM

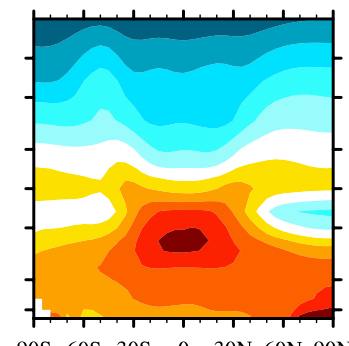

90S $60 \mathrm{~S} 30 \mathrm{~S} \quad 0 \quad 30 \mathrm{~N} 60 \mathrm{~N} 90 \mathrm{~N}$

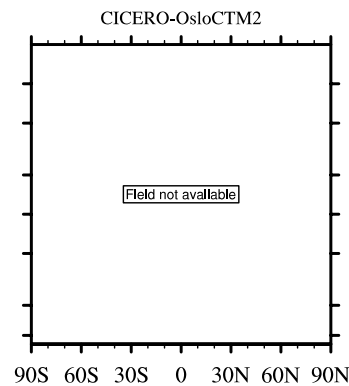

GISS-E2-R

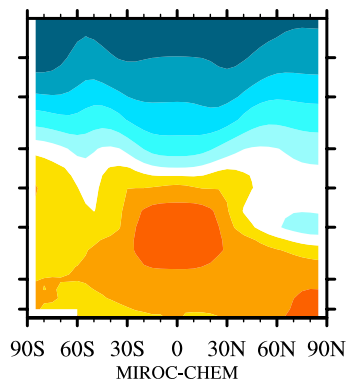

MIROC-CHEM

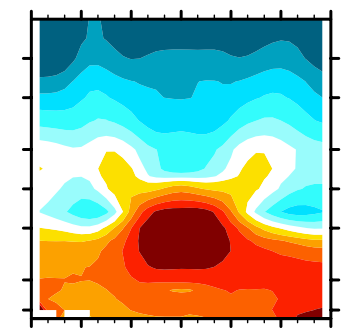

$90 \mathrm{~S} 60 \mathrm{~S} \quad 30 \mathrm{~S} \quad 0 \quad 30 \mathrm{~N} 60 \mathrm{~N} 90 \mathrm{~N}$ STOC-HadAM3

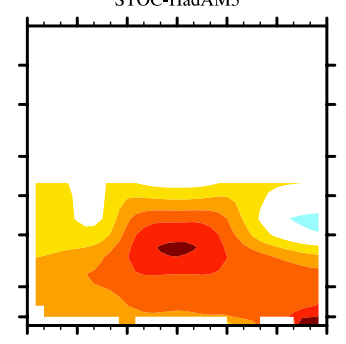

$90 \mathrm{~S} 60 \mathrm{~S} 30 \mathrm{~S} \quad 0 \quad 30 \mathrm{~N} 60 \mathrm{~N} 90 \mathrm{~N}$
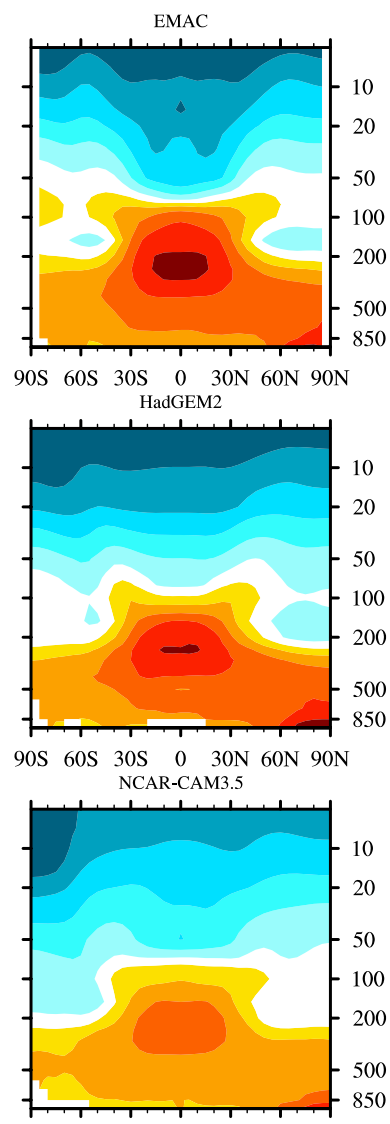

$90 \mathrm{~S} 60 \mathrm{~S} 30 \mathrm{~S} \quad 0 \quad 30 \mathrm{~N} 60 \mathrm{~N} 90 \mathrm{~N}$

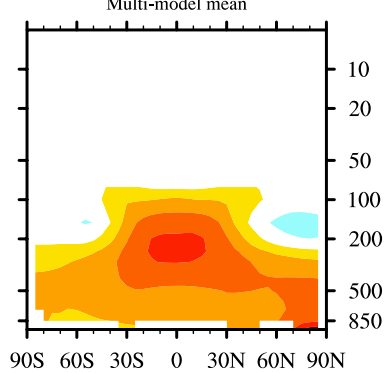

Fig. 11c. Same as (b) but for RCP8.5.

of Earth System interactions and feedbacks (Arneth et al., 2010a).

The analysis of climate diagnostics (precipitation, temperature, specific humidity and zonal wind) indicates that most models overestimate global annual precipitation, albeit the recent analysis by Stephens et al. (2012) tend to considerably weaken this statement. Models exhibit have a cold bias in the lower troposphere $(700 \mathrm{hPa}$, i.e. the region of maximum $\mathrm{OH}$ in the tropics), similar to the CMIP3 models (Randall et al., 2007). The specific humidity change between 1850 and 2000 is an overall increase, except for GFDL-AM3 (and
MIROC-CHEM to a lesser extent), which shows a strong decrease in the northern mid-latitudes. Furthermore, the comparison of the changes between 2000 and 2100 shows significant differences (compared to the rest of the models) in specific humidity of CESM-CAM-Superfast and temperature of NCAR-CAM3.5, especially in the case of RCP2.6, related to their use of CMIP3-based SSTs.

The 16 models described in this paper were used to perform the simulations needed for the analysis of various topics, namely (1) aerosols and total radiative forcing (Shindell et al., 2012), (2) tropospheric ozone changes (Young et al., 
2012), (3) ozone radiative forcing and attribution (Stevenson et al., 2012), (4) comparison of ozone and associated forcing with TES (Bowman et al., 2012), (5) black carbon deposition (Lee et al., 2012), and (6) OH and methane lifetime in the historical (Naik et al., 2012a) and future (Voulgarakis et al., 2012) periods. Additional contributions and simulations are also planned for future analysis, focusing on air quality issues and additional understanding of simulated trends.

The structures built for ACCMIP have been designed to follow the conventions used in the climate modeling community as much as possible. This should greatly facilitate comparisons between the ACCMIP models and CMIP5 models, as well as between ACCMIP models and the many datasets that are being used for evaluation of CMIP5 models. It is hoped that the range of tools developed for the ACCMIP activity, including the CMOR tables, the archive structure, and analyses codes, will be useful for subsequent of chemistryclimate model intercomparisons and model evaluation efforts against observations.

\section{Supplementary material related to this article is available online at: http://www.geosci-model-dev.net/6/ 179/2013/gmd-6-179-2013-supplement.pdf.}

Acknowledgements. ACCMIP is organized under the auspices of Atmospheric Chemistry and Climate (AC\&C), a project of International Global Atmospheric Chemistry (IGAC) and Stratospheric Processes And their Role in Climate (SPARC) under the International Geosphere-Biosphere Project (IGBP) and World Climate Research Program (WCRP). The authors are grateful to the British Atmospheric Data Centre (BADC), which is part of the NERC National Centre for Atmospheric Science (NCAS), for collecting and archiving the ACCMIP data. D. S., G. F. and Y. L. acknowledge support from the NASA MAP and ACMAP programs. D. P. would like to thank the Canadian Foundation for Climate and Atmospheric Sciences for their long-running support of CMAM development. S. G. was supported by the US Department of Energy Office of Science Decadal and Regional Climate Prediction using Earth System Models (EaSM) program. The Pacific Northwest National Laboratory (PNNL) is operated for the DOE by Battelle Memorial Institute under contract DE-AC06-76RLO 1830. The work of D. B. and P. C. was funded by the US Dept. of Energy (BER), performed under the auspices of LLNL under Contract DE-AC52-07NA27344, and used the supercomputing resources of NERSC under contract No. DE-AC02-05CH11231. V. E. and M. R. were supported by the DLR Earth System Model Validation Project (ESMVal) and used the supercomputing resources of the German Climate Computing Center (DKRZ) and the Leibniz Supercomputing Centre (LRZ) for the EMAC simulations. The work of I. C. was funded by the ENEA National Integrated Model to support the international negotiation on atmospheric pollution (Minni) project. W. J. C., G. A. F. and S. T. R. were supported by the Joint DECC and Defra Integrated Climate Programme (GA01101). V. N. and L. W. H. acknowledge efforts of GFDL's Global Atmospheric Model Development Team in the development of the GFDL-AM3 and Modeling Services Group for assistance with data processing. G. Z. acknowledges NIWA HPCF facility and funding from New Zealand Ministry of Science and Innovation. The GEOSCCM work was supported by the NASA Modeling, Analysis and Prediction program, with computing resources provided by NASA's High-End Computing Program through the NASA Advanced Supercomputing Division. The STOC-HadAM3 work was supported by cross UK research council grant NE/I008063/1 and used facilities provided by the UK's national high-performance computing service, HECToR, through Computational Modelling Services (CMS), part of the NERC National Centre for Atmospheric Science (NCAS). The LMDz-OR-INCA simulations were done using computing resources provided by the CCRT/GENCI computer center of the CEA. The MIROC-CHEM calculations were performed on the NIES supercomputer system (NEC SX-8R), and supported by the Environment Research and Technology Development Fund (S-7) of the Ministry of the Environment, Japan. The CICERO-OsloCTM2 simulations were done within the projects SLAC (Short Lived Atmospheric Components) and EarthClim funded by the Norwegian Research Council. The MOCAGE simulations were supported by Météo-France and CNRS. Supercomputing time was provided by Météo-France/DSI supercomputing center. The CESM project (which includes CESM-CAM-Superfast, NCAR-CAM3.5 and NCAR-CAM5.1) is supported by the National Science Foundation and the Office of Science (BER) of the US Department of Energy. The National Center for Atmospheric Research is operated by the University Corporation for Atmospheric Research under sponsorship of the National Science Foundation.

Edited by: H. Tost

\section{References}

Adler, R. F., Huffman, G. J., Chang, A., Ferraro, R., Xie, P., Janowiak, J., Rudolf, B., Schneider, U., Curtis, S., Bolvin, D., Gruber, A., Susskind, J., and Arkin, P.: The version 2 global precipitation climatology project (GPCP) monthly precipitation analysis (1979-Present), J. Hydrometeorol., 4, 1147-1167, 2003.

Allen, D. J. and Pickering, K. E.: Evaluation of lightning flash rate parameterizations for use in a global chemical transport model, J. Geophys. Res., 107, 4711, doi:10.1029/2002JD002066, 2002.

Arneth, A., Harrison, S. P., Zaehle, S., Tsigaridis, K., Menon, S., Bartlein, P. J., Feichter, J., Korhola, A., Kulmala, M., O'Donnell, D., Schurgers, G., Sorvari, S., and Vesala, T.: Terrestrial biogeochemical feedbacks in the climate system, Nat. Geosci., 3, 525-532, doi:10.1038/ngeo905, 2010a.

Arneth, A., Sitch, S., Bondeau, A., Butterbach-Bahl, K., Foster, P., Gedney, N., de Noblet-Ducoudré, N., Prentice, I. C., Sanderson, M., Thonicke, K., Wania, R., and Zaehle, S.: From biota to chemistry and climate: towards a comprehensive description of trace gas exchange between the biosphere and atmosphere, Biogeosciences, 7, 121-149, doi:10.5194/bg-7-121-2010, $2010 \mathrm{~b}$.

Bechtold, P., Bazile, E., Guichard, F., Mascart, P., and Richard, E.: A mass flux convection scheme for regional and global models, Q. J. R. Meteorol. Soc., 127, 869-886, 2001.

Bian, H. and Prather, M. J.: Fast-J2: accurate simulation of stratospheric photolysis in global chemical models, J. Atmos. Chem., 
41, 281-296, 2002.

Bowman, K., Shindell, D., Worden, H., Lamarque, J. F., Young, P. J., Stevenson, D., Qu, Z., de la Torre, M., Bergmann, D., Cameron-Smith, P., Collins, W. J., Doherty, R., Dalsøren, S., Faluvegi, G., Folberth, G., Horowitz, L. W., Josse, B., Lee, Y. H., MacKenzie, I., Myhre, G., Nagashima, T., Naik, V., Plummer, D., Rumbold, S., Skeie, R., Strode, S., Sudo, K., Szopa, S., Voulgarakis, A., Zeng, G., Kulawik, S., and Worden, J.: Observational constraints on ozone radiative forcing from the Atmospheric Chemistry Climate Model Intercomparison Project (ACCMIP), Atmos. Chem. Phys. Discuss., 12, 23603-23644, doi:10.5194/acpd-12-23603-2012, 2012.

Butkovskaya, N., Kukui, A., and Le Bras, G.: $\mathrm{HNO}_{3}$ forming channel of the $\mathrm{HO}_{2}+\mathrm{NO}$ reaction as a function of pressure and temperature in the ranges of 72-600 Torr and 223-323 K, J. Phys. Chem. A., 111, 9047-9053, 2007.

Cagnazzo, C., Manzini, E., Giorgetta, M. A., Forster, P. M. De F., and Morcrette, J. J.: Impact of an improved shortwave radiation scheme in the MAECHAM5 General Circulation Model, Atmos. Chem. Phys., 7, 2503-2515, doi:10.5194/acp-7-2503-2007, 2007.

Chang, J. S., Brost, R. A., Isaksen, I. S. A., Madronich, S., Middleton, P., Stockwell, W. R., and Walcek, C. J.: A three-dimensional Eulerian acid deposition model: physical concepts and formulation, J. Geophys. Res., 92, 14681-14700, 1987.

Cionni, I., Eyring, V., Lamarque, J.-F., Randel, W. J., Stevenson, D. S., Wu, F., Bodeker, G. E., Shepherd, T. G., Shindell, D. T., and Waugh, D. W.: Ozone database in support of CMIP5 simulations: results and corresponding radiative forcing, Atmos. Chem. Phys., 11, 11267-11292, doi:10.5194/acp11-11267-2011, 2011.

Collins, W. J., Derwent, R. G., Johnson, C. E., and Stevenson, D. S.: A comparison of two schemes for the convective transport of chemical species in a Lagrangian global chemistry model, Q. J. R. Meteorol. Soc., 128, 991-1009, 2002.

Collins, W. J., Bellouin, N., Doutriaux-Boucher, M., Gedney, N., Halloran, P., Hinton, T., Hughes, J., Jones, C. D., Joshi, M., Liddicoat, S., Martin, G., O'Connor, F., Rae, J., Senior, C., Sitch, S., Totterdell, I., Wiltshire, A., and Woodward, S.: Development and evaluation of an Earth-System model - HadGEM2, Geosci. Model Dev., 4, 1051-1075, doi:10.5194/gmd-4-10512011, 2011.

Dee, D. P., Uppala, S. M., Simmons, A. J., Berrisford, P., Poli, P., Kobayashi, S., Andrae, U., Balmaseda, M. A., Balsamo, G., Bauer, P., Bechtold, P., Beljaars, A. C. M., van de Berg, L., Bidlot, J., Bormann, N., Delsol, C., Dragani, R., Fuentes, M., Geer, A. J., Haimberger, L., Healy, S. B., Hersbach, H., Hólm, E. V., Isaksen, L., Kållberg, P., Köhler, M., Matricardi, M., McNally, A. P., Monge-Sanz, B. M., Morcrette, J. J., Park, B. K., Peubey, C., de Rosnay, P., Tavolato, C., Thépaut, J. N., and Vitart, F.: The ERA-Interim reanalysis: configuration and performance of the data assimilation system, Q. J. R. Meteorol. Soc., 137, 553-597, 2011.

Dentener, F., Kinne, S., Bond, T., Boucher, O., Cofala, J., Generoso, S., Ginoux, P., Gong, S., Hoelzemann, J. J., Ito, A., Marelli, L., Penner, J. E., Putaud, J.-P., Textor, C., Schulz, M., van der Werf, G. R., and Wilson, J.: Emissions of primary aerosol and precursor gases in the years 2000 and 1750 prescribed data-sets for AeroCom, Atmos. Chem. Phys., 6, 4321-
4344, doi:10.5194/acp-6-4321-2006, 2006.

Donner, L. J., Wyman, B. L., Hemler, R. S., Horowitz, L. W., Ming, Y., Zhao, M., Golaz, J.-C., Ginoux, P., Lin, S.-J., Schwarzkopf, M. D., Austin, J., Alaka, G., Cooke, W. F., Delworth, T. L., Freidenreich, S. M., Gordon, C. T., Griffies, S. M., Held, I. M., Hurlin, W. J., Klein, S. A., Knutson, T. R., Langenhorst, A. R., Lee, H.-C., Lin, Y., Magi, B. I., Malyshev, S. L., Milly, P. C., Naik, V., Nath, M. J., Pincus, R., Ploshay, J. J., Ramaswamy, V., Seman, C. J., Shevliakova, E., Sirutis, J. J., Stern, W. F., Stouffer, R. J., Wilson, R. J., Winton, M., Wittenberg, A. T., and Zeng, F.: The dynamical core, physical parameterizations, and basic simulation characteristics of the atmospheric component of the GFDL global coupled model CM3, J. Climate, 24, 3484-3519, doi:10.1175/2011JCLI3955.1, 2011.

Emanuel, K. A.: A scheme for representing cumulus convection in large-scale models, J. Atmos. Sci., 48, 2313-2335, 1991.

Emanuel, K. A.: A cumulus representation based on the episodic mixing model: the importance of mixing and microphysics in predicting humidity, AMS. Meteorol. Monogr., 24, 185-192, 1993.

Ganzeveld, L. N., van Aardenne, J. A., Butler, T. M., Lawrence, M. G., Metzger, S. M., Stier, P., Zimmermann, P., and Lelieveld, J.: Technical Note: Anthropogenic and natural offline emissions and the online EMissions and dry DEPosition submodel EMDEP of the Modular Earth Submodel system (MESSy), Atmos. Chem. Phys. Discuss., 6, 5457-5483, doi:10.5194/acpd-6-5457-2006, 2006.

Giannakopoulos, C., Chipperfield, M. P., Law, K. S., and Pyle, J. A.: Validation and intercomparison of wet and dry deposition schemes using ${ }^{210} \mathrm{~Pb}$ in a global 3-D offline chemistry model, J. Geophys. Res., 104, 23761-23784, 1999.

Gregory, D. and Rowntree, P. R.: A mass flux scheme with representation of cloud ensemble characteristics and stability-dependent closure, Mon. Weather Rev., 118, 1483-1506, 1990.

Grewe, V., Brunner, D., Dameris, M., Grenfell, J. L., Hein, R., Shindell, D., Staehelin, J.: Origin and variability of upper tropospheric nitrogen oxides and ozone at northern mid-latitudes, Atmos. Environ., 35, 3421-3433, 2001.

Guenther, A., Karl, T., Harley, P., Wiedinmyer, C., Palmer, P. I., and Geron, C.: Estimates of global terrestrial isoprene emissions using MEGAN (Model of Emissions of Gases and Aerosols from Nature), Atmos. Chem. Phys., 6, 3181-3210, doi:10.5194/acp-63181-2006, 2006.

Hough, A. M.: The calculation of photolysis rates for use in global tropospheric modelling studies, AERE Report R-13259, HMSO, London, 1988.

Huijnen, V., Williams, J., van Weele, M., van Noije, T., Krol, M., Dentener, F., Segers, A., Houweling, S., Peters, W., de Laat, J., Boersma, F., Bergamaschi, P., van Velthoven, P., Le Sager, P., Eskes, H., Alkemade, F., Scheele, R., Nédélec, P., and Pätz, H.-W.: The global chemistry transport model TM5: description and evaluation of the tropospheric chemistry version 3.0, Geosci. Model Dev., 3, 445-473, doi:10.5194/gmd-3-445-2010, 2010.

Hurrell, J.W., Hack, J. J., Shea, D, Caron, J.M. and Rosinski, J. : A New Sea Surface Temperature and Sea Ice Boundary Dataset for the Community Atmosphere Model, J. Climate, 21, 5145-5153, 2008. 
Jacob, D. and Winner, D. A., Effect of climate change on air quality, Atmos. Env., 43, 51-63, doi:10.1016/j.atmosenv.2008.09.051, 2009.

Jaeglé L., Steinberger, L., Martin, R. V., and Chance, K.: Global partitioning of $\mathrm{NO}_{x}$ sources using satellite observations: Relative roles of fossil fuel combustion, biomass burning and soil emissions, Faraday Discuss., 130, 407-423, 2005.

Jöckel, P., Tost, H., Pozzer, A., Brühl, C., Buchholz, J., Ganzeveld, L., Hoor, P., Kerkweg, A., Lawrence, M. G., Sander, R., Steil, B., Stiller, G., Tanarhte, M., Taraborrelli, D., van Aardenne, J., and Lelieveld, J.: The atmospheric chemistry general circulation model ECHAM5/MESSy1: consistent simulation of ozone from the surface to the mesosphere, Atmos. Chem. Phys., 6, 50675104, doi:10.5194/acp-6-5067-2006, 2006.

Jones, C. D., Hughes, J. K., Bellouin, N., Hardiman, S. C., Jones, G. S., Knight, J., Liddicoat, S., O'Connor, F. M., Andres, R. J., Bell, C., Boo, K.-O., Bozzo, A., Butchart, N., Cadule, P., Corbin, K. D., Doutriaux-Boucher, M., Friedlingstein, P., Gornall, J., Gray, L., Halloran, P. R., Hurtt, G., Ingram, W. J., Lamarque, J.-F., Law, R. M., Meinshausen, M., Osprey, S., Palin, E. J., Parsons Chini, L., Raddatz, T., Sanderson, M. G., Sellar, A. A., Schurer, A., Valdes, P., Wood, N., Woodward, S., Yoshioka, M., and Zerroukat, M.: The HadGEM2-ES implementation of CMIP5 centennial simulations, Geosci. Model Dev., 4, 543-570, doi:10.5194/gmd-4-543-2011, 2011.

Josse, B., Simon, P., and Peuch, V. H.: Radon global simulations with the multiscale chemistry and transport model MOCAGE, Tellus-B, 56, 339-356, 2004.

Koch, D., Schmidt, G. A., and Field, C. V.: Sulfur, sea salt and radionuclide aerosols in GISS Model E, J. Geophys. Res., 111, D06206, doi:10.1029/2004JD005550, 2006.

Lamarque, J.-F., Bond, T. C., Eyring, V., Granier, C., Heil, A., Klimont, Z., Lee, D., Liousse, C., Mieville, A., Owen, B., Schultz, M. G., Shindell, D., Smith, S. J., Stehfest, E., Van Aardenne, J., Cooper, O. R., Kainuma, M., Mahowald, N., McConnell, J. R., Naik, V., Riahi, K., and van Vuuren, D. P.: Historical (1850-2000) gridded anthropogenic and biomass burning emissions of reactive gases and aerosols: methodology and application, Atmos. Chem. Phys., 10, 7017-7039, doi:10.5194/acp10-7017-2010, 2010.

Lamarque, J.-F., Kyle, G. P., Meinshausen, M., Riahi, K., Smith, S. J., van Vuuren, D. P., Conley, A., and Vitt, F.: Global and regional evolution of short-lived radiatively-active gases and aerosols in the representative concentration pathways, Climatic Change, 109, 191-212, doi:10.1007/s10584-011-0155-0, 2011.

Lamarque, J.-F., Emmons, L. K., Hess, P. G., Kinnison, D. E., Tilmes, S., Vitt, F., Heald, C. L., Holland, E. A., Lauritzen, P. H., Neu, J., Orlando, J. J., Rasch, P. J., and Tyndall, G. K.: CAM-chem: description and evaluation of interactive atmospheric chemistry in the Community Earth System Model, Geosci. Model Dev., 5, 369-411, doi:10.5194/gmd-5-369-2012, 2012.

Landgraf, J. and Crutzen, P. J.: An efficient method for online calculations of photolysis and heating rates, J. Atmos. Sci., 55, 863 878,1998

Law, K. S. and Pyle, J. A.: Modelling trace gas budgets in the troposphere, Part 1: ozone and odd nitrogen, J. Geophys. Res., 98, 18377-18400, 1993.
Lee, Y. H. and Adams, P. J.: A fast and efficient version of the two-moment aerosol sectional (TOMAS) global aerosol microphysics model, Aerosol Sci. Tech., 46, 678-689, doi:10.1080/02786826.2011.643259, 2011.

Lee, Y. H., Lamarque, J.-F., Flanner, M. G., Jiao, C., Shindell, D. T., Berntsen, T., Bisiaux, M. M., Cao, J., Collins, W. J., Curran, M., Edwards, R., Faluvegi, G., Ghan, S., Horowitz, L. W., McConnell, J. R., Myhre, G., Nagashima, T., Naik, V., Rumbold, S. T., Skeie, R. B., Sudo, K., Takemura, T., and Thevenon, F.: Evaluation of preindustrial to present-day black carbon and its albedo forcing from ACCMIP (Atmospheric Chemistry and Climate Model Intercomparison Project), Atmos. Chem. Phys. Discuss., 12, 21713-21778, doi:10.5194/acpd-12-21713-2012, 2012.

Li, D. and Shine, K. P.: A 4-Dimensional Ozone Climatology for UGAMP Models, UGAMP Internal Report No. 35, April 1995, available at: http://badc.nerc.ac.uk/data/ugamp-o3-climatology/ ugamp_help.html(last access: 15 June 2012), Available from the British Atmospheric Data Centre, 1995.

Liu, C., Allan, R. P., and Huffman, G. J.: Co-variation of temperature and precipitation in CMIP5 models and satellite observations, Geophys. Res. Lett., 39, L13803, doi:10.1029/2012GL052093, 2012.

Liu, X., Easter, R. C., Ghan, S. J., Zaveri, R., Rasch, P., Shi, X., Lamarque, J.-F., Gettelman, A., Morrison, H., Vitt, F., Conley, A., Park, S., Neale, R., Hannay, C., Ekman, A. M. L., Hess, P., Mahowald, N., Collins, W., Iacono, M. J., Bretherton, C. S., Flanner, M. G., and Mitchell, D.: Toward a minimal representation of aerosols in climate models: description and evaluation in the Community Atmosphere Model CAM5, Geosci. Model Dev., 5, 709-739, doi:10.5194/gmd-5-709-2012, 2012.

Martin, R. V., Sauvage, B., Folkins, I., Sioris, C. E., Boone, C., Bernath, P., and Ziemke, J.: Space-based constraints on the production of nitric oxide by lightning, J. Geophys. Res., 112, D09309, doi:10.1029/2006JD007831, 2007.

McLinden, C. A., Olsen, S., Hannegan, B., Wild, O., Prather, M. J., and Sundet, J.: Stratospheric ozone in 3-D models: a simple chemistry and the cross-tropopause flux, J. Geophys. Res., 105, 14653-14665, 2000.

Meehl, G. A., Stocker, T. F., Collins, W. D., Friedlingstein, P., Gaye, A. T., Gregory, J. M., Kitoh, A., Knutti, R., Murphy, J. M., Noda, A., Raper, S. C. B., Watterson, I. G., Weaver, A. J., and Zhao, Z.-C.: Global climate projections, in: Climate Change 2007: The Physical Science Basis, Contribution of Working Group I to the Fourth Assessment Report of the Intergovernmental Panel on Climate Change, edited by: Solomon, S., Qin, D., Manning, M., Chen, Z., Marquis, M., Averyt, K. B., Tignor, M., and Miller, H. L., 747-845, Cambridge University Press, Cambridge, UK and New York, NY, USA, 2007.

Meinshausen, M., Smith, S. J., Calvin, K., Daniel, J. S., Kainuma, M. L. T., Lamarque, J.-F., Matsumoto, K., Montzka, S., Raper, S., Riahi, K., Thomson, A., Velders, G. J. M., and van Vuuren, D. P.: The RCP greenhouse gas concentrations and their extensions from 1765 to 2300, Climatic Change, 109, 213-241, doi:10.1007/s10584-011-0156-z, 2011.

Moorthi, S. and Suarez, M. J.: Relaxed Arakawa-Schubert, a parameterization of mosit convection for general-circulation models, Mon. Weather Rev, 120, 978-1002, 1992.

Naik, V., Voulgarakis, A., Fiore, A. M., Horowitz, L. W., Lamarque, J.-F., Lin, M., Prather, M. J., Young, P. J., Bergmann, D., 
Cameron-Smith, P. J., Cionni, I., Collins, W. J., Dalsøren, S. B., Doherty, R., Eyring, V., Faluvegi, G., Folberth, G. A., Josse, B., Lee, Y. H., MacKenzie, I. A., Nagashima, T., van Noije, T. P. C., Plummer, D. A., Righi, M., Rumbold, S. T., Skeie, R., Shindell, D. T., Stevenson, D. S., Strode, S., Sudo, K., Szopa, S., and Zeng, G.: Preindustrial to present day changes in tropospheric hydroxyl radical and methane lifetime from the Atmospheric Chemistry and Climate Model Intercomparison Project (ACCMIP), Atmos. Chem. Phys. Discuss., 12, 30755-30804, doi:10.5194/acpd-1230755-2012, 2012a.

Naik, V., Horowitz, L. W., Fiore, A. M., Ginoux, P., Mao, J., Aghedo, A., and Levy II, H.: Preindustrial to present day impact of changes in short-lived pollutant emissions on atmospheric composition and climate forcing, J. Geophys. Res., submitted, $2012 b$.

O’Connor, F., Boucher, M. O., Gedney, N., Jones, C. D., Folberth, G. A., Coppell, R., Friedlingstein, P., Collins, W. J., Chappellaz, J., Ridley, J., and Johnson, C. E.: Possible role of wetlands, permafrost, and methane hydrates in the methane cycle under future climate change: a review, Rev. Geophys., 48, RG4005, doi:10.1029/2010RG000326, 2010.

Oman, L. D., Ziemke, J. R., Douglass, A. R., Waugh, D. W., Lang, C., Rodriguez, J. M., and Nielsen, J. E.: The response of tropical tropospheric ozone to ENSO, Geophys. Res. Lett., 38, L13706, doi:10.1029/2011GL047865, 2011.

Pendergrass, A. G. and Hartmann, D. L.: Global-mean precipitation and black carbon in AR4 simulations, Geophys. Res. Lett., 39, L01703, doi:10.1029/2011GL050067, 2012.

Price, C. and Rind, D.: A simple lightning parameterization for calculating global lightning distributions, J. Geophys. Res., 97, 9919-9933, doi:10.1029/92JD00719, 1992.

Price, C., Penner, J., and Prather, M.: $\mathrm{NO}_{\mathrm{x}}$ from lightning 1. Global distribution based on lightning physics, J. Geophys. Res., 102, 5929-5941, doi:10.1029/96JD03504, 1997.

Randall, D. A., Wood, R. A., Bony, S., Colman, R., Fichefet, T., Fyfe, J., Kattsov, V., Pitman, A., Shukla, J., Srinivasan, J., Stouffer, R. J., Sumi, A., and Taylor, K. E.: Climate Models and their evaluation, in: Climate Change 2007: The Physical Science Basis, Contribution of Working Group I to the Fourth Assessment Report of the Intergovernmental Panel on Climate Change, 589662, edited by: Solomon, S., Qin, D., Manning, M., Chen, Z., Marquis, M., Averyt, K. B., Tignor, M., and Miller, H. L., Cambridge University Press, Cambridge, United Kingdom and New York, NY, USA, 2007.

Ridley, B. A., Pickering, K. E., and Dye, J. E.: Comments on the parameterization of lightning-produced NO in global chemistrytransport models, Atmos. Environ., 39, 6184-6187, 2005.

Rotstayn, L. D., Jeffrey, S. J., Collier, M. A., Dravitzki, S. M., Hirst, A. C., Syktus, J. I., and Wong, K. K.: Aerosol- and greenhouse gas-induced changes in summer rainfall and circulation in the Australasian region: a study using single-forcing climate simulations, Atmos. Chem. Phys., 12, 6377-6404, doi:10.5194/acp-126377-2012, 2012.

Sander, S.P., Abbatt, J., Barker, J. R., Burkholder, J. B., Friedl, R. R., Golden, D. M., Huie, R. E., Kolb, C. E., Kurylo, M. J., Moortgat, G. K., Orkin, V. L. and Wine, P. H.: Chemical Kinetics and Photochemical Data for Use in Atmospheric Studies, Evaluation No. 17, JPL Publication 10-6, Jet Propulsion Laboratory, Pasadena, 2011.
Schulz, M.: Constraining model estimates of the aerosol radiative forcing, Thèse d'Habilitation à Diriger des Recherches, Université Pierre et Marie Curie, Paris VI, 2007.

Schulz, M., Balkanski, Y., Dulac, F., and Guelle, W.: Role of aerosol size distribution and source location in a three-dimensional simulation of a Saharan dust episode tested against satellite derived optical thickness, J. Geophys. Res., 103, 10579-10592, 1998.

Scinocca, J. F. and McFarlane, N. A.: The variability of modelled tropical precipitation, J. Atmos. Sci., 61, 1993-2015, 2004.

Scinocca, J. F., McFarlane, N. A., Lazare, M., Li, J., and Plummer, D.: Technical Note: The CCCma third generation AGCM and its extension into the middle atmosphere, Atmos. Chem. Phys., 8, 7055-7074, doi:10.5194/acp-8-7055-2008, 2008.

Shindell, D. T., Grenfell, J. L., Rind, D., Price, C., and Grewe, V.: Chemistry climate interactions in the Goddard Institute for Space Studies general circulation model 1: tropospheric chemistry model description and evaluation, J. Geophys. Res., 106, 80478076, 2001.

Shindell, D. T., Levy II, H., Schwarzkopf, M. D., Horowitz, L. W., Lamarque, J.-F., and Faluvegi, G.: Multi-model projections of climate change from short-lived emissions due to human activities. J. Geophys. Res., 113, D11109, doi:10.1029/2007JD009152, 2008.

Shindell, D. T., Lamarque, J.-F., Schulz, M., Flanner, M., Jiao, C., Chin, M., Young, P., Lee, Y. H., Rotstayn, L., Milly, G., Faluvegi, G., Balkanski, Y., Collins, W. J., Conley, A. J., Dalsoren, S., Easter, R., Ghan, S., Horowitz, L., Liu, X., Myhre, G., Nagashima, T., Naik, V., Rumbold, S., Skeie, R., Sudo, K., Szopa, S., Takemura, T., Voulgarakis, A., and Yoon, J.-H.: Radiative forcing in the ACCMIP historical and future climate simulations, Atmos. Chem. Phys. Discuss., 12, 21105-21210, doi:10.5194/acpd-12-21105-2012, 2012a.

Shindell, D. T., Pechony, O., Voulgarakis, A., Faluvegi, G., Nazarenko, L., Lamarque, J.-F., Bowman, K., Milly, G., Kovari, B., Ruedy, R., and Schmidt, G.: Interactive ozone and methane chemistry in GISS-E2 historical and future climate simulations, Atmos. Chem. Phys. Discuss., 12, 23513-23602, doi:10.5194/acpd-12-23513-2012, 2012 b.

Skeie, R. B., Berntsen, T., Myhre, G., Pedersen, C. A., Ström, J., Gerland, S., and Ogren, J. A.: Black carbon in the atmosphere and snow, from pre-industrial times until present, Atmos. Chem. Phys., 11, 6809-6836, doi:10.5194/acp-11-6809-2011, $2011 \mathrm{a}$.

Skeie, R. B., Berntsen, T. K., Myhre, G., Tanaka, K., Kvalevåg, M. M., and Hoyle, C. R.: Anthropogenic radiative forcing time series from pre-industrial times until 2010, Atmos. Chem. Phys., 11, 11827-11857, doi:10.5194/acp-11-11827-2011, 2011 b.

Søvde, O. A., Hoyle, C. R., Myhre, G., and Isaksen, I. S. A.: The $\mathrm{HNO} 3$ forming branch of the $\mathrm{HO}_{2}+\mathrm{NO}$ reaction: pre-industrialto-present trends in atmospheric species and radiative forcings, Atmos. Chem. Phys., 11, 8929-8943, doi:10.5194/acp-11-89292011, 2011.

SPARC Report on the evaluation of chemistry-climate models, edited by: Eyring, V., Shepherd, T. G., and Waugh, D. W., SPARC report No. 5, WCRP-132, WMO/TD-No 1526, 2010.

Spiro, P. A., Jacob, D. J., and Logan, J. A.: Global inventory of sulfur emissions with $1^{\circ} \times 1^{\circ}$ Resolution, J. Geophys. Res., 97, 6023-6036, 1992.

Spivakovsky, C. M., Logan, J. A., Montzka, S. A., Balkanski, Y. J., Foreman-Fowler, M., Jones, D. B. A., Horowitz, L. W., 
Fusco, A. C., Brenninkmeijer, C. A. M., Prather, M. J., Wofsy, S. C., and McElroy, M. B.: Three-dimensional climatological distribution of tropospheric $\mathrm{OH}$ : update and evaluation, J. Geophys. Res., 105, 8931-8980, 2000.

Steinkamp, J. and Lawrence, M. G.: Improvement and evaluation of simulated global biogenic soil NO emissions in an AC-GCM, Atmos. Chem. Phys., 11, 6063-6082, doi:10.5194/acp-11-60632011, 2011.

Stephens, G. L., Juilin, L., Wild., M., Clayson, C. A., Loeb, N., Kato, S., L'Ecuyer, T., Stackhouse Jr., P. W., Lebsock, M., and Andrews, T.: An update on Earth's energy balance in light of the latest global observations, Nat. Geosci., 5, 691-696, doi:, 2012.

Stevenson, D. S., Doherty, R. M., Sanderson, M. G., Collins, W. J., Johnson, C. E., and Derwent, R. G.: Radiative forcing from aircraft $\mathrm{NO}_{\mathrm{x}}$ emissions: mechanisms and seasonal dependence, $\mathrm{J}$. Geophys. Res., 109, D17307, doi:10.1029/2004JD004759, 2004.

Stevenson, D. S., Dentener, F. J., Schultz, M. G., Ellingsen, K., van Noije, T. P. C., Wild, O., Zeng, G., Amann, M., Atherton, C. S., Bell, N., Bergmann, D. J., Bey, I., Butler, T., Cofala, J., Collins, W. J., Derwent, R. G., Doherty, R. M., Drevet, J., Eskes, H. J., Fiore, A. M., Gauss, M., Hauglustaine, D. A., Horowitz, L. W., Isaksen, I. S. A., Krol, M. C., Lamarque, J.F., Lawrence, M. G., Montanaro, V., Müller, J.-F., Pitari, G., Prather, M. J., Pyle, J. A., Rast, S., Rodriguez, J. M., Sanderson, M. G., Savage, N. H., Shindell, D. T., Strahan, S. E., Sudo, K., and Szopa, S.: Multi-model ensemble simulations of present-day andnear-future tropospheric ozone. J. Geophys. Res., 111, D08301, doi:10.1029/2005JD006338, 2005.

Stevenson, D. S., Young, P. J., Naik, V., Lamarque, J.-F., Shindell, D. T., Voulgarakis, A., Skeie, R. B., Dalsoren, S. B., Myhre, G., Berntsen, T. K., Folberth, G. A., Rumbold, S. T., Collins, W. J., MacKenzie, I. A., Doherty, R. M., Zeng, G., van Noije, T. P. C., Strunk, A., Bergmann, D., Cameron-Smith, P., Plummer, D. A., Strode, S. A., Horowitz, L., Lee, Y. H., Szopa, S., Sudo, K., Nagashima, T., Josse, B., Cionni, I., Righi, M., Eyring, V., Conley, A., Bowman, K. W., and Wild, O.: Tropospheric ozone changes, radiative forcing and attribution to emissions in the Atmospheric Chemistry and Climate Model Inter-comparison Project (ACCMIP), Atmos. Chem. Phys. Discuss., 12, $26047-$ 26097, doi:10.5194/acpd-12-26047-2012, 2012.

Szopa, S., Balkanski, Y., Schulz, M., Bekki, S., Cugnet, D., Fortems-Cheiney, A., Turquety, S., Cozic, A., Déandreis, C., Hauglustaine, D., Idelkadi, A., Lathière, J., Lefèvre, F., Marchand, M., Vuolo, R., Yan, N., and Dufresne, J.-L.: Aerosol and ozone changes as forcing for climate evolution between 1850 and 2100, Clim. Dynam., doi:doi:10.1007/s00382-012-1408-y, 2012.

Taylor, K. E., Stouffer, R. J., and Meehl, G. A.: An overview of CMIP5 and the experiment design, B. Am. Meteorol. Soc., 93, 485-498, 2012.

Teyssèdre, H., Michou, M., Clark, H. L., Josse, B., Karcher, F., Olivié, D., Peuch, V.-H., Saint-Martin, D., Cariolle, D., Attié, J.L., Nédélec, P., Ricaud, P., Thouret, V., van der A, R. J., VolzThomas, A., and Chéroux, F.: A new tropospheric and stratospheric Chemistry and Transport Model MOCAGE-Climat for multi-year studies: evaluation of the present-day climatology and sensitivity to surface processes, Atmos. Chem. Phys., 7, 58155860, doi:10.5194/acp-7-5815-2007, 2007.
Tiedtke, M.: A comprehensive mass flux scheme for cumulus parameterization in large-scale models, Mon. Weather Rev., 117, 1779-1800, 1989.

van Vuuren, D. P., Edmonds, J., Kainuma, M., Riahi, K., Thomson, A., Hibbard, K., Hurtt, G. C., Kram, T., Krey, V., Lamarque, J.-F., Matsui, T., Meinshausen, M., Nakicenovic, N., and Smith, S. J., and Rose, S. K.: The representative concentration pathways: an overview, Climatic Change, 109, 5-31, doi:10.1007/s10584-011-0148-z, 2011.

Voulgarakis, A., Naik, V., Lamarque, J.-F., Shindell, D. T., Young, P. J., Prather, M. J., Wild, O., Field, R. D., Bergmann, D., CameronSmith, P., Cionni, I., Collins, W. J., Dalsøren, S. B., Doherty, R. M., Eyring, V., Faluvegi, G., Folberth, G. A., Horowitz, L. W., Josse, B., McKenzie, I. A., Nagashima, T., Plummer, D. A., Righi, M., Rumbold, S. T., Stevenson, D. S., Strode, S. A., Sudo, K., Szopa, S., and Zeng, G.: Analysis of present day and future $\mathrm{OH}$ and methane lifetime in the ACCMIP simulations, Atmos. Chem. Phys. Discuss., 12, 22945-23005, doi:10.5194/acpd-1222945-2012, 2012.

Watanabe, S., Hajima, T., Sudo, K., Nagashima, T., Takemura, T., Okajima, H., Nozawa, T., Kawase, H., Abe, M., Yokohata, T., Ise, T., Sato, H., Kato, E., Takata, K., Emori, S., and Kawamiya, M.: MIROC-ESM 2010: model description and basic results of CMIP5-20c3m experiments, Geosci. Model Dev., 4, 845-872, doi:10.5194/gmd-4-845-2011, 2011.

Wesely, M. L.: Parameterization of surface resistances to gaseous dry deposition in regional-scale numerical models, Atmos. Environ., 23, 1293-1304, 1989.

Wild, O., Zhu, X., and Prather, M. J., Fast-J: accurate simulation of in- and belowcloud photolysis in global chemical models, J. Atmos. Chem. 37, 245-282, 2000

Yienger, J. J. and Levy, H.: Empirical model of global soil-biogenic $\mathrm{NO}_{\mathrm{x}}$ emissions, J. Geophys. Res., 100, 11447-11464, 1995.

Young, P. J., Archibald, A. T., Bowman, K. W., Lamarque, J.-F., Naik, V., Stevenson, D. S., Tilmes, S., Voulgarakis, A., Wild, O., Bergmann, D., Cameron-Smith, P., Cionni, I., Collins, W. J., Dalsøren, S. B., Doherty, R. M., Eyring, V., Faluvegi, G., Horowitz, L. W., Josse, B., Lee, Y. H., MacKenzie, I. A., Nagashima, T., Plummer, D. A., Righi, M., Rumbold, S. T., Skeie, R. B., Shindell, D. T., Strode, S. A., Sudo, K., Szopa, S., and Zeng, G.: Pre-industrial to end 21st century projections of tropospheric ozone from the Atmospheric Chemistry and Climate Model Intercomparison Project (ACCMIP), Atmos. Chem. Phys. Discuss., 12, 21615-21677, doi:10.5194/acpd-12-21615-2012, 2012.

Zhang, G. J. and McFarlane, N. A.: Sensitivity of climate simulations to the parameterization of cumulus convection in the Canadian Climate Center general circulation model, Atmos. Ocean, 33, 407-446, 1995.

Zeng, G., Pyle, J. A., and Young, P. J.: Impact of climate change on tropospheric ozone and its global budgets, Atmos. Chem. Phys., 8, 369-387, doi:10.5194/acp-8-369-2008, 2008.

Zeng, G., Morgenstern, O., Braesicke, P., and Pyle, J. A.: Impact of stratospheric ozone recovery on tropospheric ozone and its budget, Geophys. Res. Lett., 37, L09805, doi:10.1029/2010GL042812, 2010. 